\title{
Reassessing the Productivity Gains from Trade Liberalization
}




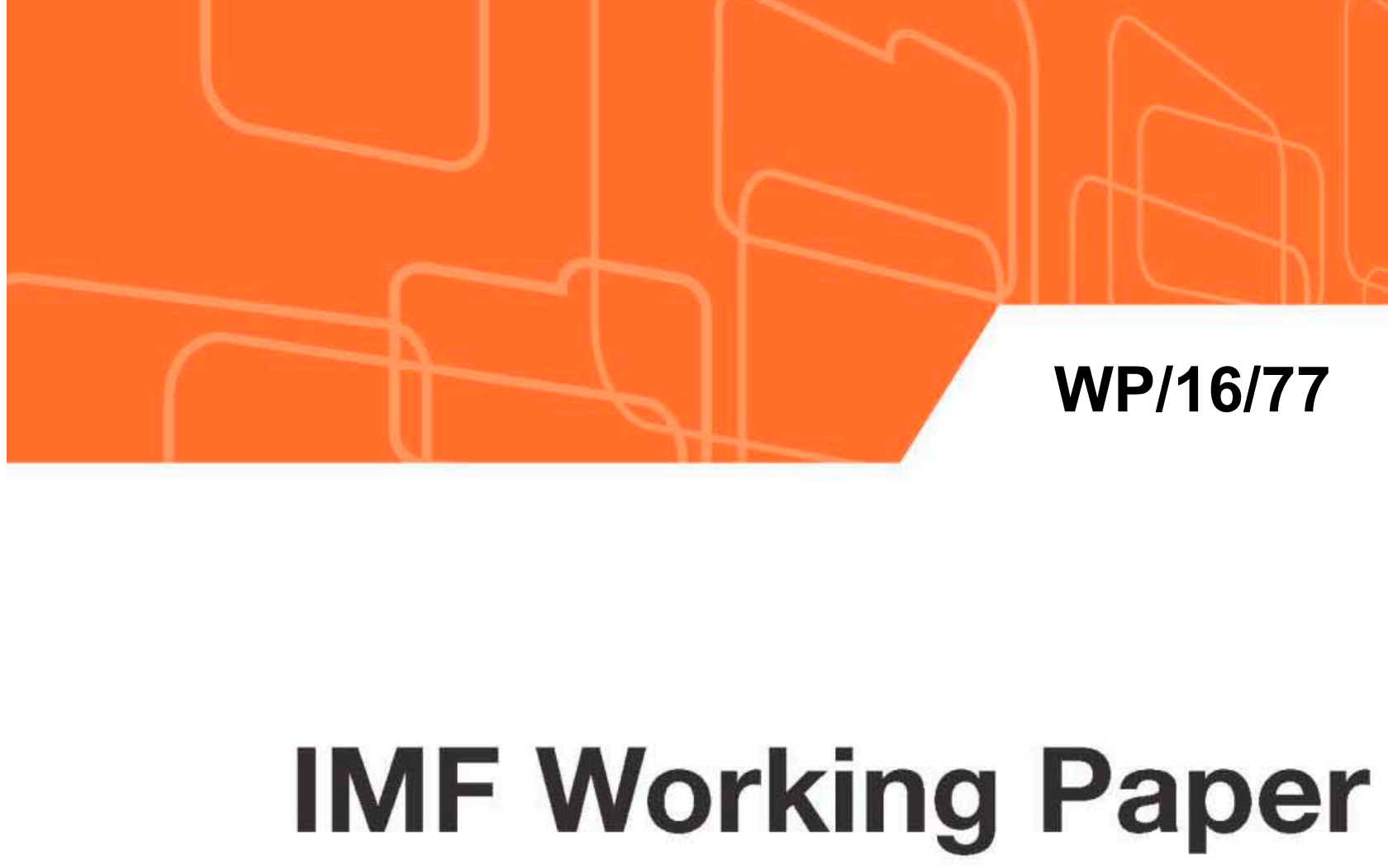

Reassessing the Productivity Gains from Trade Liberalization

By JaeBin Ahn, Era Dabla-Norris, Romain Duval, Bingjie Hu and Lamin Njie

I N T ER N A T I O N A L M O NETAR Y FU N D 


\title{
IMF Working Paper
}

Fiscal Affairs and Research Departments

\author{
Reassessing the Productivity Gains from Trade Liberalization \\ Prepared by JaeBin Ahn, Era Dabla-Norris, Romain Duval, Bingjie Hu and Lamin Njie \\ Authorized for distribution by Era Dabla-Norris and Romain Duval
}

March 2016

IMF Working Papers describe research in progress by the author(s) and are published to elicit comments and to encourage debate. The views expressed in IMF Working Papers are those of the author(s) and do not necessarily represent the views of the IMF, its Executive Board, or IMF management.

\begin{abstract}
This paper reassesses the impact of trade liberalization on productivity. We build a new, unique database of effective tariff rates at the country-industry level for a broad range of countries over the past two decades. We then explore both the direct effect of liberalization in the sector considered, as well as its indirect impact in downstream industries via input linkages. Our findings point to a dominant role of the indirect input market channel in fostering productivity gains. A 1 percentage point decline in input tariffs is estimated to increase total factor productivity by about 2 percent in the sector considered. For advanced economies, the implied potential productivity gains from fully eliminating remaining tariffs are estimated at around 1 percent, on average, which do not factor in the presumably larger gains from removing existing non-tariff barriers. Finally, we find strong evidence of complementarities between trade and FDI liberalization in boosting productivity. This calls for a broad liberalization agenda that cuts across different areas.
\end{abstract}

JEL Classification Numbers:F13, F14, F21, F43, O43.

Keywords: Trade, Productivity, Tariffs, Inputs, Liberalization, FDI, Reforms, Growth.

Author's E-Mail Address: jahn@imf.org; edablanorris@imf.org; rduval@imf.org; bhu@imf.org; lnjie@,imf.org 


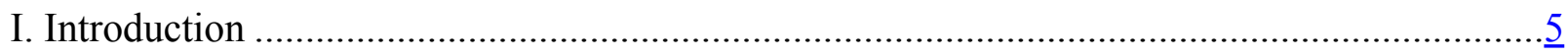

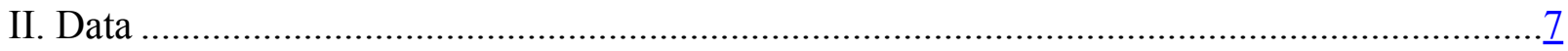

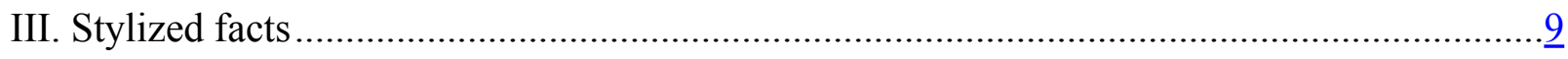

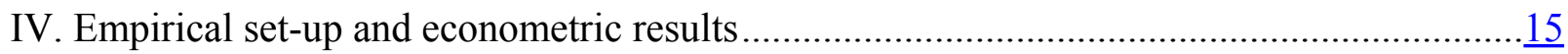

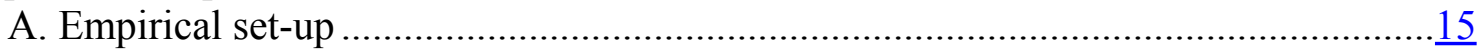

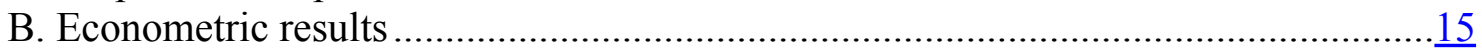

C. Robustness Checks ................................................................................. $\frac{18}{23}$

D. Policy Implications of the Results ...........................................................

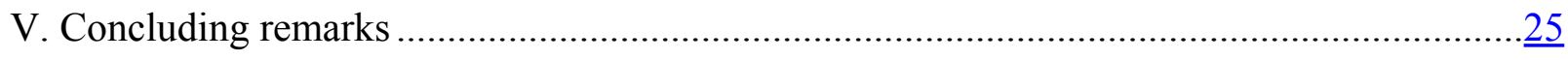

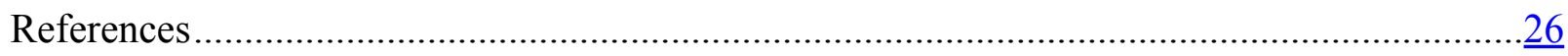

Tables

1. Baseline regression: Total Factor Productivity ......................................................... 16

2. Baseline regression: Labor Productivity ............................................................... 16

3. Complementarity between tariff and FDI liberalization: Total Factor Productivity ............... 18

4. Complementarity between tariff and FDI liberalization: Labor Productivity .......................18

5. Robustness checks for baseline regressions: alternative output and input tariff measures.......20

6. Robustness checks for baseline regressions: interpolated tariff data and changes in sample...20

7. Robustness checks for tariff-FDI complementarity regressions: TFP; alternative output and

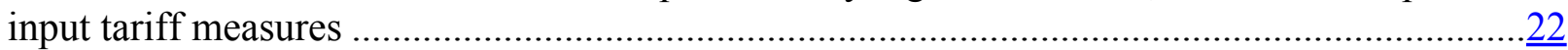

8. Robustness checks for tariff-FDI complementarity regressions: LP; alternative output and

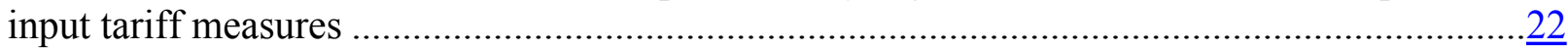

9. Robustness checks for tariff-FDI complementarity regressions: TFP; interpolated tariff data

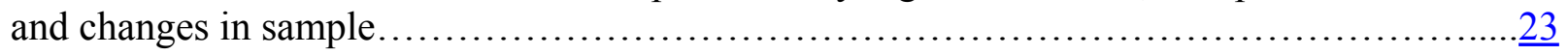
10. Robustness checks for tariff-FDI complementarity regressions: LP; interpolated tariff

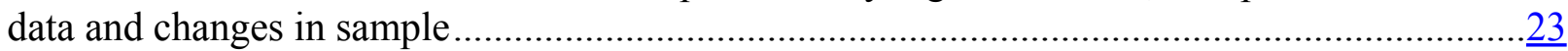

Figures

1. Effective Tariff and Most-Favored-Nation (MFN) Tariff Rates .......................................10

2. Changes in Aggregates Tariff Barriers over 1997-2007 ............................................... 11

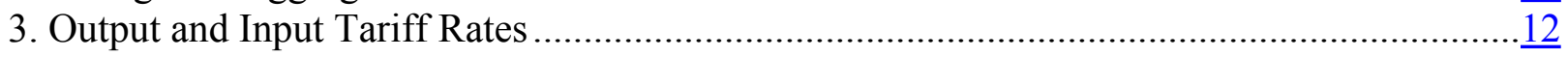

4. Heterogeneity in Tariff Rate Changes across Sectors..................................................... $\frac{13}{14}$

5a. Total Factor Productivity (TFP) and Output Tariff Rates............................................ 14

5b. Total Factor Productivity (TFP) and Input Tariff Rates ................................................14

6. Potential Productivity Gains from Eliminating Remaining Tariff Barriers ...........................24 
Annex Tables

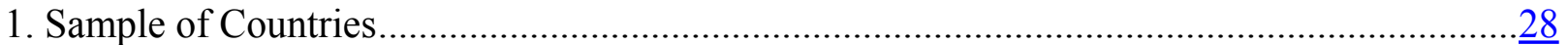

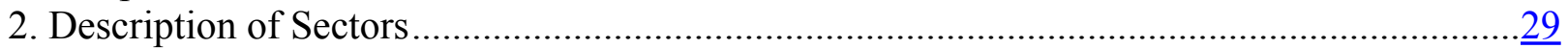

3. Baseline Sample Data Countries and Sectors .............................................................

4. Concordance between FDI restrictiveness indicators and the baseline data......................... 31 


\section{INTRODUCTION}

Trade liberalization is one of the main potential avenues for countries to boost productivity levels. This issue features high on policymakers' agendas, as exemplified by the recent TransPacific Partnership (TPP) agreement. Major liberalization has been achieved in the past, but efforts have stalled more recently and there remains some scope for further progress even in advanced economies, particularly as regards to non-tariff barriers to trade and foreign direct investment (FDI).

Over and above the classical gains arising from the reallocation of resources across sectors, the literature identifies several channels through which trade liberalization can boost productivity and, hence output. First, lower trade and FDI barriers can strengthen competition in the liberalized sector(s), putting pressure on domestic producers to lower price margins, exploit economies of scale (Helpman and Krugman, 1985), improve efficiency, absorb foreign technology, or innovate (Aghion and others, 2005). Second, productivity gains from liberalization may accrue disproportionately to larger and more productive firms, enabling them to gain market share and amplifying aggregate gains within the liberalized sector (Melitz, 2003; Pavcnik, 2002). Third, trade liberalization can boost productivity by increasing the quality and variety of intermediate inputs available to domestic producers (Ethier, 1982; Grossman and Helpman, 1991; Markusen, 1989). Recent firm-level evidence for a number of countries confirms the quantitative importance of this input channel (Fernandes, 2007; Kasahara and Rodrigue, 2008; Topalova and Khandelwal, 2011; Amiti and Konings, 2013; Halpern et al., 2015).

Another important result from recent theoretical and empirical evidence is that the impact of the input channel - and that of trade liberalization more broadly - appears to vary widely across firms depending on their individual characteristics, such as ownership status (foreignowned vs. domestic, see Halpern et al., 2015), the extent to which they use imported inputs (Amiti and Konings, 2007) or the degree of competition in their industry (Topalova and Khandelwal, 2011). This hints at possible interactions between trade liberalization and other policies, such as product market regulation or barriers to FDI that could affect these firm characteristics.

This paper reassesses the productivity gains arising from tariff cuts on final goods and intermediate inputs and their complementarities with reductions in barriers to FDI. We use a new, unique database of effective tariffs in 18 sectors across 18 advanced countries spanning over two decades. The productivity effects of both "output tariffs", which capture competitive pressures from liberalization in the sector considered, and "input tariffs", which capture the input channel, are assessed empirically. For each country and year observation, the effective output tariff in each sector $j$ is computed as a weighted average of most-favored-nation (MFN), preferential tariff and non-MFN rates, where weights reflect the relative importance of the 
individual products and trading partners to which each type of rate applies. For each country and year, the effective input tariff in each sector $j$ is then computed as a weighted average of output tariff rates in all sectors, with weights calculated using Input-Output (IO) matrices for each individual country, taking into account all input linkages. That is, we factor in the fact that tariff changes affect not only the imported inputs but also the domestic ones insofar as the latter are produced using imported inputs from other sectors.

Our three-dimensional panel econometric analysis finds a significant and robust impact of input tariff liberalization on sector-level total factor productivity (TFP), which is much stronger than the effect of output tariff liberalization. In other words, the input variety and/or quality channels that underpin the input tariff effect appear to matter more for boosting productivity than the pro-competition impact of lower output tariffs. Quantitatively, the estimates imply that a one percentage reduction in input tariffs raises TFP levels by about two percent. In addition, the effect of both output and input tariff liberalization are greater when barriers to FDI are lower, highlighting the importance of complementarities between trade and FDI liberalization.

Our results are robust across different specifications. Using alternative lags of the output and input tariff variables, different measures of productivity and time periods, as well as alternative clustering strategies - at country-sector or country-year level - for standard errors only has a limited quantitative impact on the results. We also try to capture competitive pressures in an alternative way, by considering the effective rate of protection a la Corden (1966) — which takes into account potential anti-competitive forces from both high output tariffs and low input tariffs — instead of the output tariff rate; again, results are virtually identical.

While tariff barriers in advanced countries have been reduced substantially over the last decades, our analysis suggests that there remains some scope for further reductions, and therefore for additional productivity gains. A back-of-the-envelope calculation of the potential productivity gains from full elimination of remaining tariffs suggests that aggregate productivity could rise, on average, by around 1 percent across advanced economies, varying from about 0.2 percent in Japan to 7.7 percent in Ireland, depending on both remaining sectorlevel tariff rates and each sector's importance in the country considered. For instance, potential productivity gains for Korea and Ireland are estimated to be larger than those for other advanced economies mainly because of comparatively high remaining tariffs in Korea and the importance of specific sectors for Ireland - the chemical and pharmaceutical industries, which dominate potential productivity gains. Given their comparatively higher tariff barriers to trade, emerging and low-income economies could benefit from tariff liberalization even more than advanced economies, on average.

Our paper makes several contributions to the existing literature. We build the first comprehensive dataset of effective import tariffs across countries, sectors and time, starting, and aggregating up from bilateral imports from each partner country at the individual product 
level. Previous studies employing tariff measures (e.g, Amiti and Konings, 2007; Amiti and Khandelwal, 2013; Fernandes, 2007; Topalova and Khandelwal, 2011) typically only consider MFN rates, which have become increasingly misleading as preferential bilateral or regional agreements have gained prominence around the world.

Second, by accounting fully for the gains from resource reallocation across firms, it adds to the recent firm-level literature on trade liberalization that has emphasized the impact of input tariffs. The main advantage of using sector-level data on both tariffs and productivity is that we are able to capture the aggregate impact of liberalization on both within-firm productivity and sector-level productivity via reallocation of resources across firms, including entry and exit. While recent empirical literature essentially focuses on firm-level outcomes to examine the importance of the input channel, "new trade" theory highlights the importance of this resource reallocation across firms for overall sector-level productivity gains (Melitz, 2003; Melitz and Ottaviano, 2008). As regards interactions between trade and FDI liberalization, our results generalize most recent firm-level evidence. Using firm-level data for Hungary, Halpern et al. (2015) find that foreign firms use imported inputs more effectively and pay a lower fixed cost for importing, suggesting that by increasing foreign firm presence, lower FDI barriers could magnify the productivity impact of tariff liberalization.

Our paper also contributes to the empirical literature on the impact of market deregulation. Using sector-level EU KLEMS data and a comparable approach, Bourles et al. (2013) identify an input channel of product market liberalization, i.e. reductions in barriers to entry in upstream industries benefit most those downstream industries that use their products as inputs. Aghion et al. (2008) use state-level data for India and find that the 1991 economy-wide removal of entry barriers - the abolition of the so-called License Raj in 1991—benefited most those states that had easier labor market regulations. Our paper is the first to assess the impact of output and input tariff liberalization at the sector level across countries.

The remainder of this paper is structured as follows. Section II discusses the data, while further details on the dataset are provided in an accompanying Annex. Section III features stylized facts on effective output and input tariffs rates and their relationship with TFP. Section IV presents our empirical set-up and econometric results. Section V provides concluding remarks.

\section{DATA}

We construct a unique database of effective tariffs for 18 manufacturing and nonmanufacturing sectors across 18 advanced countries (see Annex 1 for list of countries) spanning over two decades. For each country-year observation, the effective output tariff at the product level is computed as a weighted average of most-favored-nation (MFN), preferential tariff and non-MFN rates, where weights reflect the relative importance of the individual products and trading partners to which each type of rate applies. This significantly improves on existing studies that typically consider MFN rates only. 
Specifically, we calculate the effective tariff rate for country $i$ and product $p$ in year $t$ as:

$$
\tau_{i p t}=\sum_{j}^{N_{t}^{M F N}} \omega_{i p j} M F N_{i p t}+\sum_{j}^{N_{t}^{P r e f}} \omega_{i p j} P R E F_{i p j t}+\sum_{j}^{N_{t}^{n o n M F N}} \omega_{i p j} N O N M F N_{i p t}
$$

where $M F N_{\text {ipt }}$ denotes the MFN rate applied to WTO member countries, NONMFN $N_{\text {ipt }}$ is the (typically higher) rate applied to countries that are not part of the WTO, and $P R E F_{\text {ipjt }}$ is the $j$ trading-partner-specific preferential rate under a (regional or bilateral) preferential trade agreement or under a unilateral preferential treatment such as the Generalized System of Preferences (GSP) toward developing countries. ${ }^{1}$ To calculate the country-product-level weight, $\omega_{i p j}$, we take the share of imports from country $j$ in country $i$ 's total imports of each product $p$, which is treated as a constant based on the initial year's value in order to minimize endogeneity issues. ${ }^{2}$

Product-level effective tariff rates, $\tau_{i p t}$, are then aggregated up to the 2 digit sector level using the concordance table between HS6 and ISIC.rev.3 classifications:

$$
\tau_{i s t}^{\text {output }}=\sum_{p \in S} \omega_{i p s} \tau_{i p t}
$$

where the weights, $\omega_{i p s}$, is derived from the product $p$ 's import share in country $i$ 's total imports in sector $s$.

For each country and year, the effective input tariff in each sector $s$ is then computed as a weighted average of output tariff rates in all sectors, with weights reflecting the share of imported inputs from each of these sectors used in the production of sector $s$ 's output. Considering further that the domestic portion of intermediate inputs used in sector $s$ can also be produced using imported inputs (i.e. taking into the full input-output linkages), the effective "input tariff" for sector $s$ can be expressed as:

$\tau_{i s t}^{\text {input }}=\sum_{k} \alpha_{i s k} \tau_{i k t}^{\text {output }}+\sum_{k} \beta_{i s k} \tau_{i k t}^{\text {input }}$

\footnotetext{
${ }^{1}$ A complete list of beneficiary countries for each preferential tariff regime is provided by the TRAINS database.

${ }^{2}$ Although raw tariff rates are available at HS 8 level from the TRAINS database, since trade data are available only at HS6 level from the UNComtrade database, we first take a simple average of each tariff rate across HS8 level within HS6 level, and then calculate the HS6-level effective tariff rates.
} 


$$
=\sum_{k} \alpha_{i s k} \tau_{i k t}^{\text {output }}+\sum_{k} \beta_{i s k}\left(\sum_{l} \alpha_{i k l} \tau_{i l t}^{\text {output }}+\sum_{l} \beta_{i k l} \tau_{l}^{\text {input }}\right)+\cdots
$$

So that the $N \times 1$ vector of input tariffs can be written as $[I-B]^{-1} A$, where $A$ is a $N \times 1$ matrix whose (s)th element is $\alpha_{i s k} \tau_{i k t}^{\text {output }}$ and $B$ is a $N \times N$ matrix whose $(s, k)$ th element is $\beta_{i s k}$, where $\alpha_{i s k}$ denotes the share of imported inputs from sector $k$ in total inputs used in sector $s$, while $\beta_{i s k}$ denotes the share of domestic inputs from sector $k$ in total inputs used in sector $s$, both available from the national Input-Output (IO) tables compiled by the OECD. ${ }^{3}$

We then match the resulting input and output tariff rates data with corresponding (countrysector-year-level) TFP data at the ISIC rev4 level, which are taken from the EU KLEMS and World KLEMS databases. ${ }^{4}$ These databases provide annual information on sectoral input, output, prices, and TFP over the period 1991-2012. The resulting, matched industry-level dataset of TFP and tariff rates consists largely of 13 manufacturing sectors, but a number of services sectors as well as agricultural and mining sectors are also included (see Annex 2 for description of sectors, and Annex 3 for data coverage). Actual data coverage is largely determined by the availability of the tariff data, which are missing for a few country-year observations.

Finally, in the empirical analysis we also explore interactions between tariffs and the stringency of barriers to FDI. We measure the latter by using the OECD's FDI Regulatory restrictiveness Index, which measures statutory restrictions on FDI in all of our sample countries for 22 sectors and 8 years $(1997,2003,2006-2014) .{ }^{5}$ We map the sectoral FDI restrictiveness indicators to our TFP and tariffs data using the correspondence table shown in Annex 4. In the absence of a comprehensive annual time series for the FDI restrictiveness indicators, we compute and use their average value over the sample period when testing for their interactions with tariffs in the empirical analysis.

\section{STYLIZED FACTS}

Figure 1 illustrates the systematic disparity between the simple average of MFN rates and effective tariff rates. When aggregated up to country-year level for illustrative purposes, most

\footnotetext{
${ }^{3}$ To avoid potential endogeneity and measurement issues, we pick one vintage of the input-output table and keep them constant throughout the sample period.

${ }^{4}$ The EU KLEMS database includes annual measures of output and input growth, and derived variables such as total factor productivity at the industry level. Two vintages of the database under the ISIC rev.4 and ISIC rev3 classifications were fully harmonized to be consistent at the ISIC rev4-level. See Dabla-Norris et al. (2015).

${ }^{5}$ For details, see http://www.oecd.org/investment/fdiindex.htm .
} 
of the observations lie below the 45 degree line, indicating that effective tariff rates tend to be lower than simple average MFN rates. This is not entirely straightforward a priori, since effective tariff rates incorporate both preferential rates and non-MFN rates, which are higher and lower than MFN rates, respectively. In practice, however, preferential trade agreements tend to take place between larger trading partners, while non-MFN rates tend to be applied to only a few trading partners with smaller weights. As such, deviations from the 45 degree line depend largely on the coverage and depth of regional and bilateral preferential trade agreements in each country.

Figure 1. Effective Tariff and Most-Favored-Nation (MFN)Tariff Rates (In percent; country-year level aggregates)

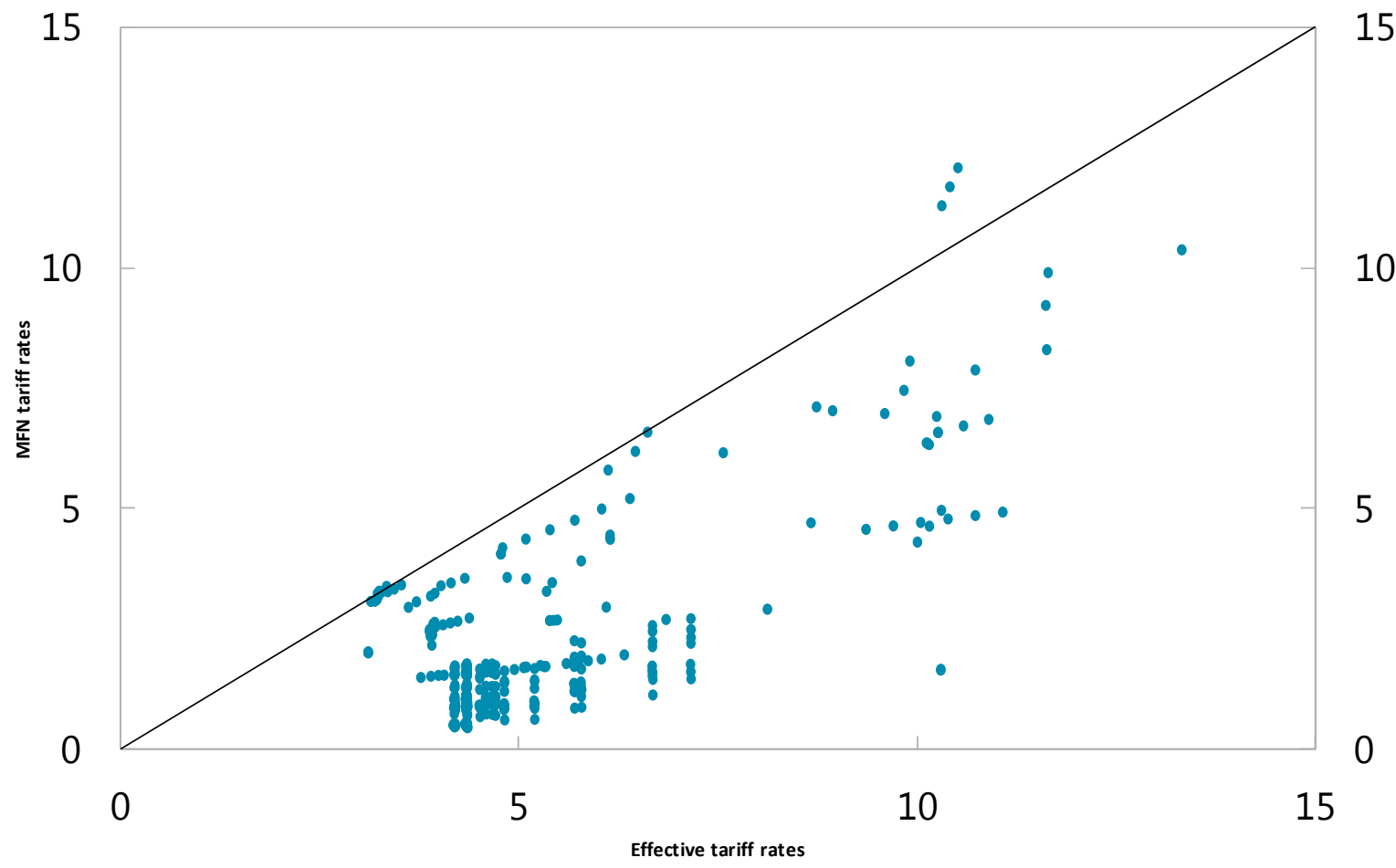

Alternatively, and more relevant of our empirical analysis, the disparity between simple average MFN rates and effective tariff rates can be illustrated in terms of changes over time. Figure 2 displays changes in tariffs - both simple average MFN and effective rates - over 10 years between 1997 and 2007 across countries. ${ }^{6}$ Two things stand out. First, except for the United States, they show different patterns. Second, these patterns are not uniform across countries. Some countries experienced a larger decline in effective rates, likely reflecting multiple preferential trade agreements that came in effect recently (e.g., Australia and Korea). At the same time, there are countries that experienced a larger decline in MFN rates, notably advanced EU member countries, where major preferential trade agreements outside the EU had

\footnotetext{
${ }^{6}$ It is over 8 years between 1997 and 2007 for Slovenia due to data availability.
} 
not taken place during the period considered. In such cases, headline measures of tariff reduction in terms of MFN rates may overstate the degree of actual reduction in tariff barriers.

Figure 2. Changes in Aggregate Tariff Barriers over 1997-2007

(In percentage point)

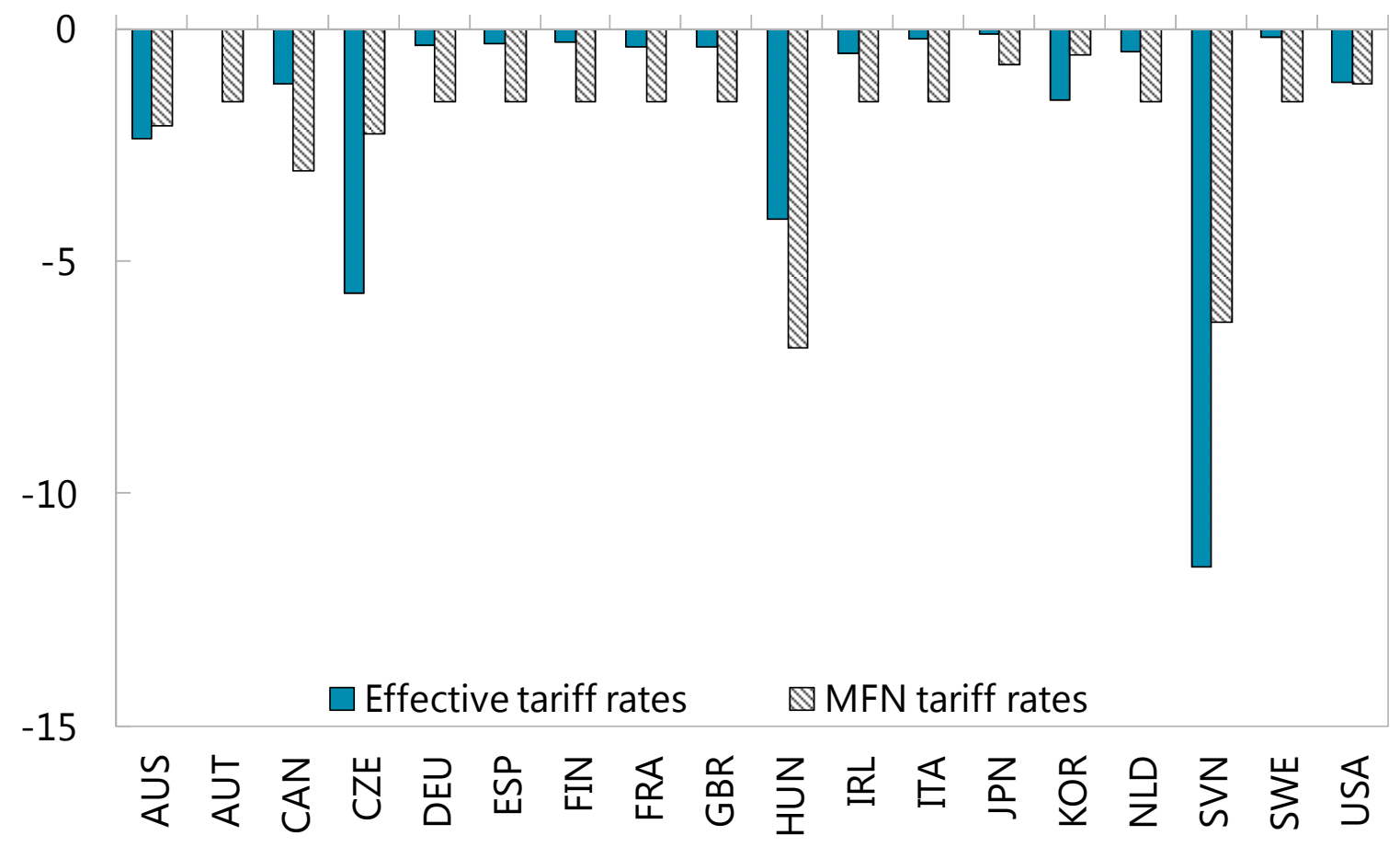

Turning to core variables in our country-sector-year-level empirical set-up, Figure 3 plots output tariff (X-axis) and input tariff ( $\mathrm{Y}$-axis) rates as deviations from country-sector averages. One of the major concerns of any approach that attempts to separately identify the output and input channels through which trade liberalization boosts productivity stems from potential collinearity between input and output tariff rates. Considering that input tariffs are constructed from output tariffs, this is not entirely implausible because input-output coefficients tend to be concentrated on diagonals - i.e., the biggest contributor to each sector's inputs tends to be its own output. Indeed, Figure 3 reveals a positive correlation between them - with a correlation coefficient of 0.49 . Importantly, this correlation is not strong enough to raise serious concerns of collinearity, as highlighted by the variation around the fitted line. 
Figure 3. Output and Input Tariff Rates

(In deviation from country-sector averages)

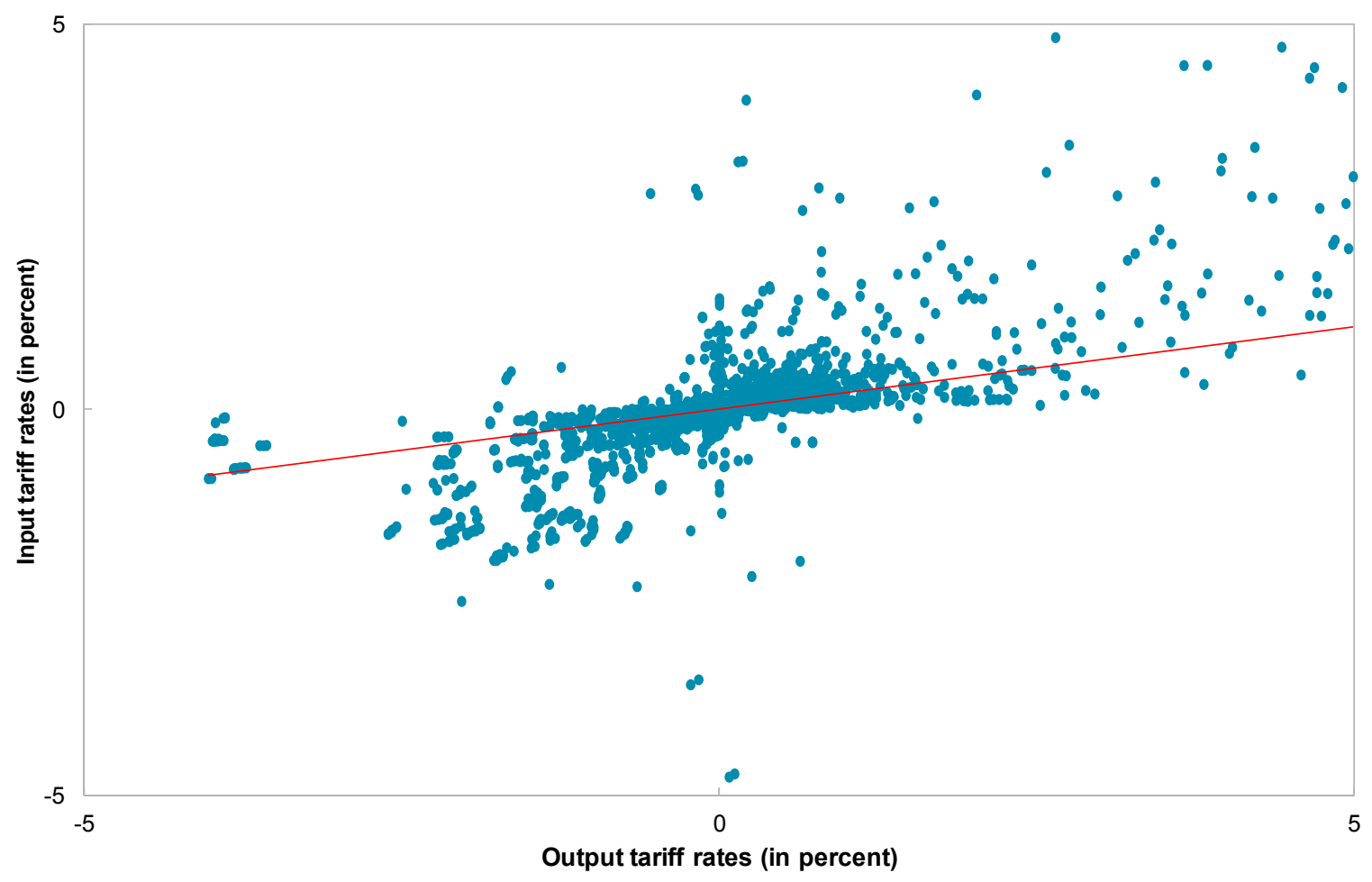

Another potential concern arises from the limited variation in tariff rates across countries. This is partly suggested by the similarity of aggregate tariff rate changes among EU member countries in Figure 2. This issue would be particularly problematic had we employed countrylevel aggregate data, and, in fact, alleviating it is one of the main advantages of the countrysector-level approach employed in this paper. Although even effective tariff rates tend to be fairly similar across countries in the common customs area, there is substantial variation in tariff rates across sectors, allowing for empirical identification of their productivity effects. This is illustrated in Figure 4 that shows changes over time in median sector-level input tariff rates among advanced EU countries. 
Figure 4. Heterogeneity in Tariff Rate Changes across Sectors (Sector-level median of input tariff rates in advanced EU countries)

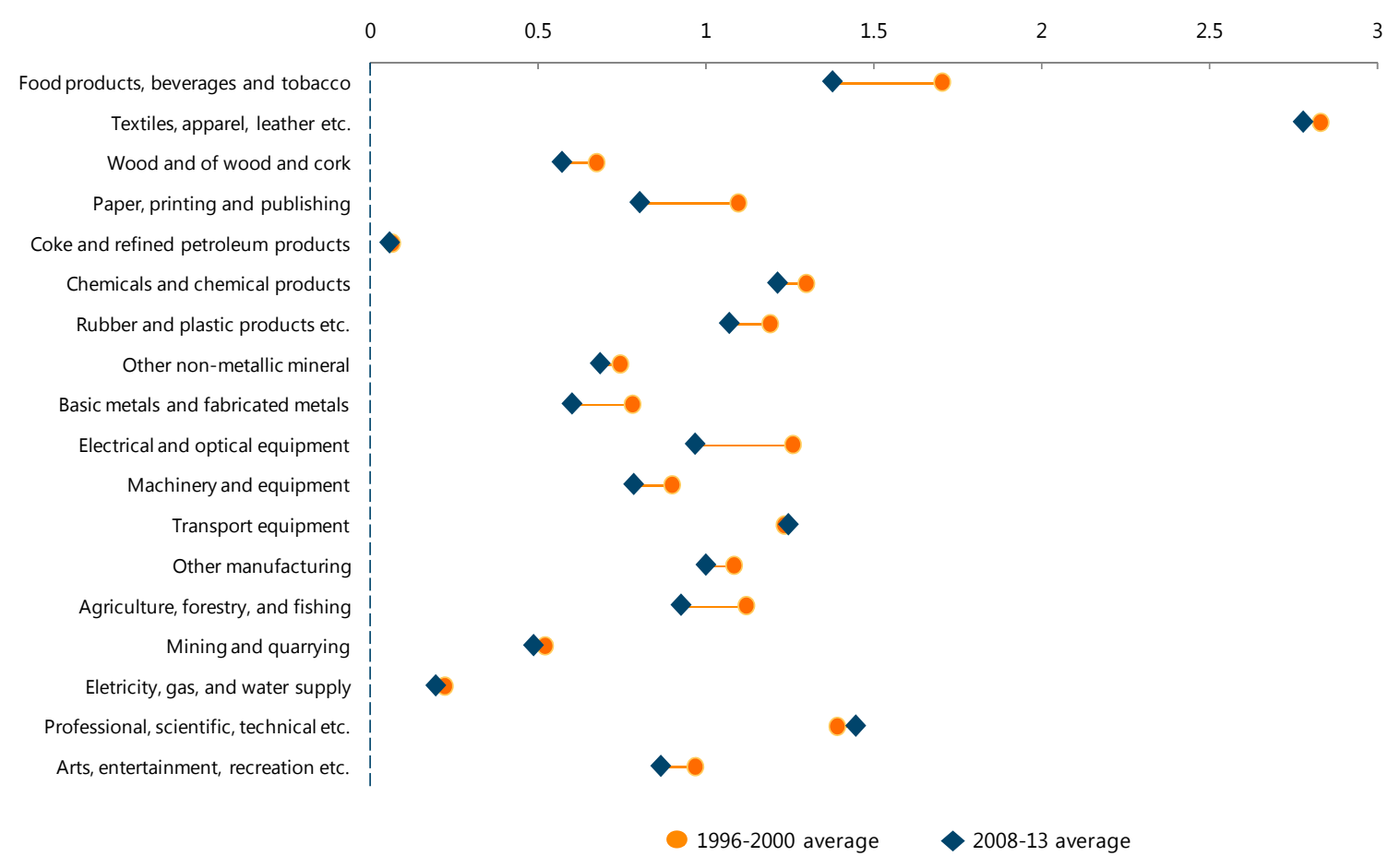

Figure 5 describes the relationship between TFP and tariff rates, the main variable of interest of our study. The above panel chart plots log TFP and output tariff rates, while the below panel chart plots log TFP and input tariff rates, all expressed in terms of deviation from countrysector averages so as to control for the role of country-sector-level fixed factors. As can be seen in the figure, compared to output tariff rates, input tariff rates appear to have a slightly stronger negative correlation with TFP, suggesting a possibly dominant productivity effect from the input channel. Subsequent sections examine this relationship using formal econometric analysis.

Figure 5 also points to a substantial number of outliers clustered around zero, i.e. clustered around values of input tariffs equal to their country-sector averages. These outliers happen to belong to either "Coke and chemical products" or "Electrical and optical equipment," and might reflect the volatility of output and prices in these industries. These observations are expected to drive the estimated impact of tariffs on TFP toward zero. Nevertheless, we systematically keep all observations in the empirical analysis that follows-removing them was not found to affect the results. 
Figure 5A. Total Factor Productivity (TFP) and Output Tariff Rates (In deviation from country-sector averages)

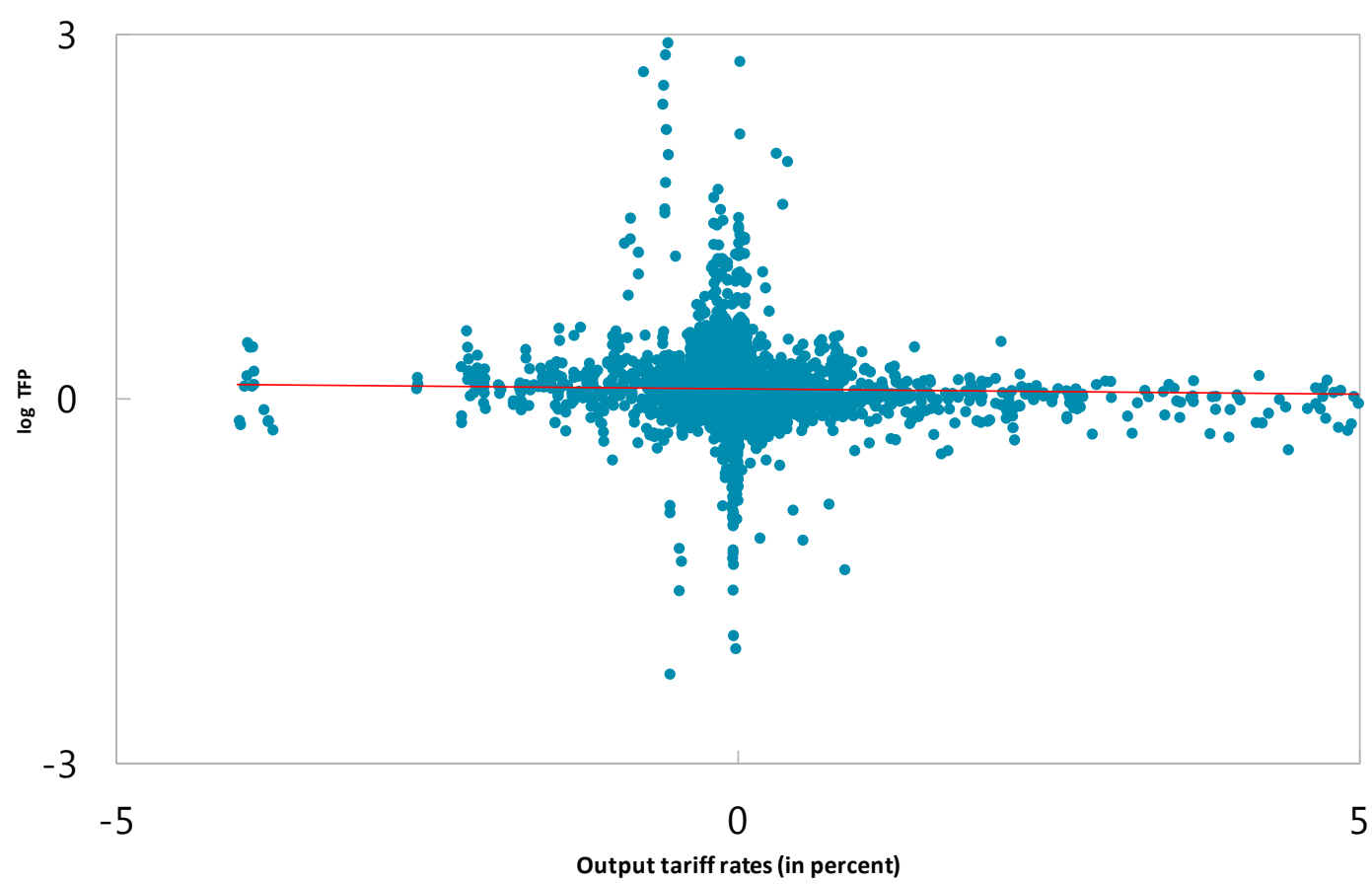

Figure 5B. Total Factor Productivity (TFP) and Input Tariff Rates (In deviation from country-sector means)

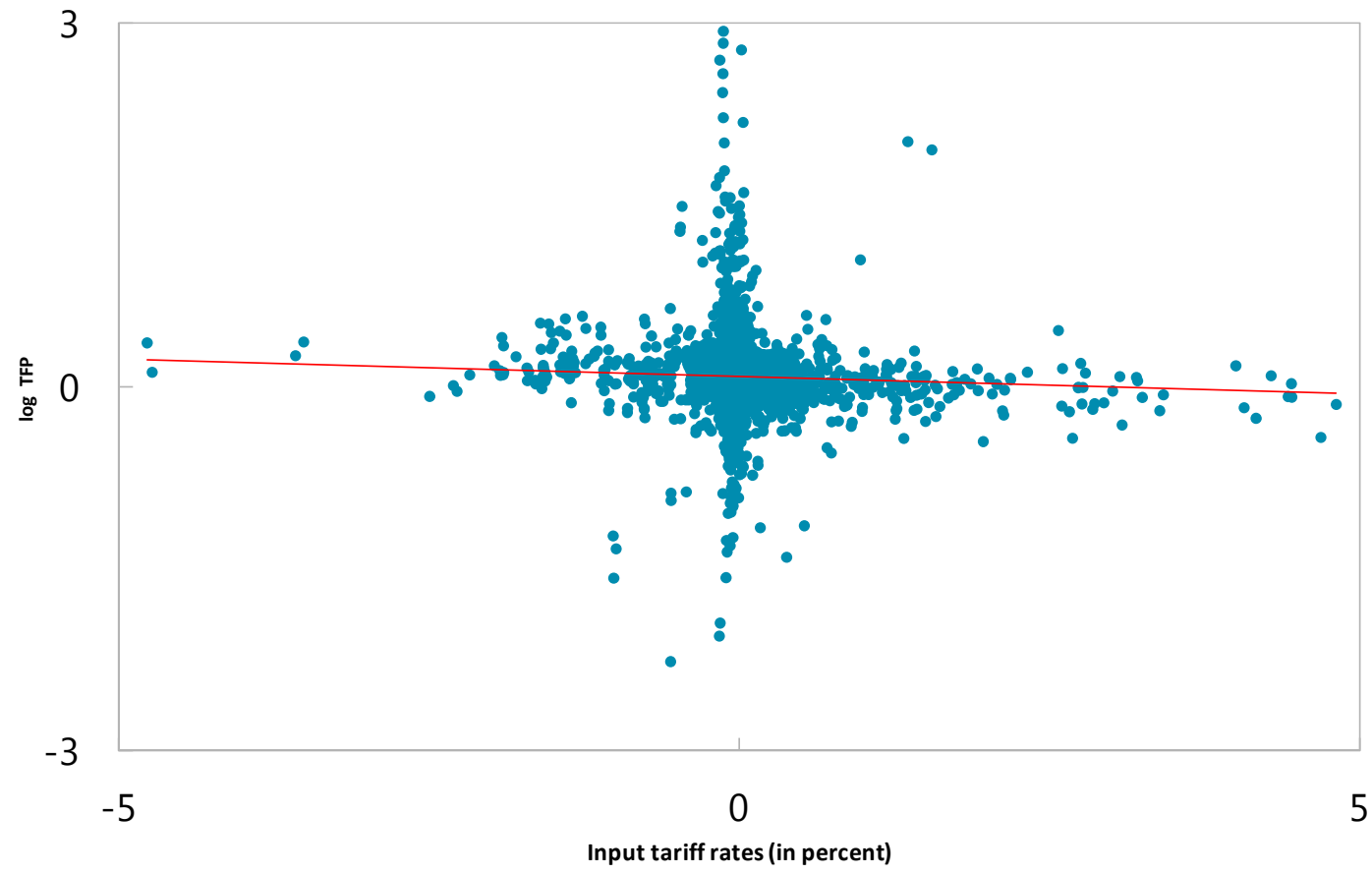

CInternational Monetary Fund. Not for Redistribution 


\section{EMPIRICAL SET-UP AND ECONOMETRIC RESULTS}

\section{A. Empirical set-up}

In order to quantify the respective effects of output and input tariffs on productivity at the country-sector level, the following empirical specification is estimated:

$\ln T F P_{i s t}=\beta_{1} \tau_{i s, t-l}^{\text {output }}+\beta_{2} \tau_{i s, t-l}^{\text {input }}+F E_{i s}+F E_{i t}+\varepsilon_{i s t}$,

where subscripts $i, s, t$ denote country, sector, and year, respectively. The dependent variable $\ln T F P_{\text {ist }}$ denotes log total factor productivity (TFP) in country $i$ and sector $s$ in year $t$, and

$\tau_{i s, t-l}^{\text {output }}$ and $\tau_{i s, t-l}^{\text {input }}$ are the corresponding country-sector-level output and input tariff rates lagged $l$ years. Given our interest in the long-run productivity impact of tariffs, we estimate the equation in levels, and use lagged tariffs to mitigate endogeneity issues. Different lag structures ( $l=1$ to 4$)$ are tested for. The specification also includes country-sector $\left(F E_{i s}\right)$ and country-year $\left(F E_{i t}\right)$ fixed effects. The country-year fixed effects control for any variation that is common to all sectors of a country's economy, including for instance aggregate output growth or reforms in other areas. The country-industry fixed effects allows us to control for industry-specific factors, including, for instance, cross-country differences in the growth of certain sectors that could arise for instance from differences in comparative advantage. This specification with fixed effects is tantamount to asking how changes in tariff rates in a given sector and country are associated with changes in productivity levels in that country-sector.

This specification is extended to test for complementarities between tariffs and barriers to FDI as follows:

$\ln T F P_{i s t}=\beta_{1} \tau_{i s, t-l}^{\text {output }}+\beta_{2} \tau_{i s, t-l}^{\text {input }}+\beta_{3} \tau_{i s, t-l} *(F D I \text { Barriers })_{i s}+F E_{i s}+F E_{i t}+\varepsilon_{i s t}$,

where (FDI Barriers) is is the average value of the OECD indicator of FDI restrictiveness in country $i$ and sector $s$ over the sample period, and $\tau_{i s, t-l}$ is the output or the input tariff rate depending on the specifications - note that the direct effect of FDI barriers on productivity is absorbed by the country-sector fixed effect $F E_{i s}$.

We estimate these equations using ordinary least squares in an unbalanced panel for the period 1991-2012. Standard errors are clustered at the country-year level. Robustness to alternative tariff measures, samples and clustering method is then performed.

\section{B. Econometric results}

Table 1 presents the baseline regression results showing the impact of output and input tariffs on TFP. We first regress (the logarithm of) TFP only on final goods tariffs. While the point estimate is negative as expected, the estimated coefficient is statistically insignificant, 
regardless of the lags considered. By contrast, input tariffs always have a strong and statistically significant impact on productivity growth when incorporated in the estimated regression. Depending on the number of lags considered, a one percentage point decline in input tariffs increases the level of TFP by 1.5 to 2.2 percent, with an average semi-elasticity of close to 2 . These results clearly show that the productivity gains from reducing input tariffs dominate those from reducing output tariffs.

Table 1. Baseline regression: Total Factor Productivity

\begin{tabular}{|c|c|c|c|c|c|c|c|c|}
\hline \multirow[t]{2}{*}{ Dependent variable: In (TFP) ist } & \multicolumn{2}{|c|}{$I=1$} & \multicolumn{2}{|c|}{$l=2$} & \multicolumn{2}{|c|}{$I=3$} & \multicolumn{2}{|c|}{$1=4$} \\
\hline & (1) & (2) & (3) & (4) & (5) & (6) & (7) & (8) \\
\hline \multirow[t]{2}{*}{ (Output tariff) ist- - } & -0.003 & -0.002 & -0.003 & -0.002 & -0.002 & -0.001 & -0.001 & -0.001 \\
\hline & $(0.003)$ & $(0.002)$ & $(0.002)$ & $(0.002)$ & $(0.002)$ & $(0.001)$ & $(0.002)$ & $(0.002)$ \\
\hline \multirow[t]{2}{*}{ (Input tariff) ist-I } & & $-0.022 * *$ & & $-0.020 * * *$ & & $-0.018^{* * *}$ & & $-0.015^{* * *}$ \\
\hline & & $(0.009)$ & & $(0.006)$ & & $(0.006)$ & & $(0.006)$ \\
\hline Country-Sector FE & Yes & Yes & Yes & Yes & Yes & Yes & Yes & Yes \\
\hline Country-Year FE & Yes & Yes & Yes & Yes & Yes & Yes & Yes & Yes \\
\hline Obs & 3,714 & 3,714 & 3,432 & 3,432 & 3,167 & 3,167 & 2,885 & 2,885 \\
\hline Adj R squared & 0.642 & 0.644 & 0.688 & 0.689 & 0.718 & 0.719 & 0.745 & 0.746 \\
\hline
\end{tabular}

Note: The dependent variable is log total factor productivity (TFP) in country i and sector s in year t. Independent variables are corresponding output and input tariff rates lagged $/$ years. Country-sector as well as country-year fixed effects are included in all columns. Standard errors in parentheses are clustered at the country-year level. Significance: ${ }^{*} 10$ percent; ${ }^{* *} 5$ percent; ${ }^{* * *} 1$ percent.

There may be a concern that the TFP estimates could be biased as TFP is measured as a residual, and any measurement errors in the labor and capital series might be captured in the estimates. To address this, we replace the TFP measure with sector-level labor productivity (LP). In Table 2 we regress log value added per hours worked in each sector on final goods and input tariffs over different time horizons. The findings presented in the table confirm our previous results. In particular, the effect from output tariffs is insignificant once we control for input tariffs, whereas the magnitude of the effect of input tariffs is very close to that estimated in the TFP regressions of Table 1.

Table 2. Baseline regression: Labor Productivity

\begin{tabular}{|c|c|c|c|c|c|c|c|c|}
\hline \multirow[t]{2}{*}{ Dependent variable: $\ln (\mathrm{LP})_{\text {ist }}$} & \multicolumn{2}{|c|}{$l=1$} & \multicolumn{2}{|c|}{$I=2$} & \multicolumn{2}{|c|}{$I=3$} & \multicolumn{2}{|c|}{$l=4$} \\
\hline & (1) & (2) & (3) & (4) & (5) & (6) & (7) & (8) \\
\hline \multirow[t]{2}{*}{ (Output tariff) ist- $I$} & -0.003 & -0.001 & -0.003 & -0.001 & -0.002 & -0.001 & -0.002 & -0.001 \\
\hline & $(0.003)$ & $(0.001)$ & $(0.002)$ & $(0.001)$ & $(0.002)$ & $(0.001)$ & $(0.002)$ & $(0.002)$ \\
\hline \multirow[t]{2}{*}{ (Input tariff) ist-I } & & $-0.024 * *$ & & $-0.022 * * *$ & & $-0.020 * * *$ & & $-0.018^{* * *}$ \\
\hline & & $(0.011)$ & & $(0.008)$ & & $(0.008)$ & & $(0.007)$ \\
\hline Country-Sector FE & Yes & Yes & Yes & Yes & Yes & Yes & Yes & Yes \\
\hline Country-Year FE & Yes & Yes & Yes & Yes & Yes & Yes & Yes & Yes \\
\hline Obs & 3,784 & 3,784 & 3,502 & 3,502 & 3,237 & 3,237 & 2,955 & 2,955 \\
\hline Adj R squared & 0.965 & 0.966 & 0.968 & 0.968 & 0.970 & 0.970 & 0.972 & 0.972 \\
\hline
\end{tabular}

Note: The dependent variable is log labor productivity (LP) in country i and sector s in year t. Independent variables are corresponding output and input tariff rates lagged $/$ years. Country-sector as well as country-year fixed effects are included in all columns. Standard errors in parentheses are clustered at the country-year level. Significance: ${ }^{*} 10$ percent; ${ }^{* *} 5$ percent; ${ }^{* * *} 1$ percent. 
We then extend our baseline regressions along the lines of equation (3) above in order to test for interactions between tariffs and FDI restrictiveness. ${ }^{7}$ We find strong evidence of complementarities between reductions in tariffs and barriers to FDI (Table 3). Input tariff reductions are estimated to have a larger impact on TFP when barriers to FDI are low. This is consistent with the evidence in Halpern et al. (2015) that foreign firms use imported inputs more effectively and pay a lower fixed cost for importing, so that their presence - which is helped by lower barriers to FDI-magnifies the productivity impact of tariff liberalization through the input channel.

Interestingly, once they are interacted with FDI restrictiveness, output tariffs show a significant, direct negative effect on TFP that was absent in Tables 1 and 2 -for countrysectors with the sample mean level of FDI restrictiveness, output tariff effect can be as strong as input tariff effects. Moreover, the estimated TFP gain from output tariff reduction is greater when barriers to FDI are lower, consistent with the notion that by increasing competitive pressure, the presence of foreign firms amplifies the productivity gain from trade liberalization through this channel. All these results are robust to considering labor productivity rather than TFP as the dependent variable (Table 4), as well as to including interactions between FDI restrictiveness and both input tariffs and output tariffs in the same specification-while also controlling for the interaction between output and input tariffs and the triple interaction between FDI restrictiveness (estimates not reported, but available upon request).

These results are also economically significant. For instance, when FDI restrictiveness is at the $75^{\text {th }}$ percentile of its cross-country and cross-sector distribution, the impact of a one percentage point fall in input tariffs on TFP ranges from 0 to 1 percent depending on the number of lags considered for the explanatory variables, while it ranges from 3 to 4 percent when FDI restrictiveness is at the $25^{\text {th }}$ percentile of its distribution.

\footnotetext{
${ }^{7}$ For the sake of easier interpretation, all the independent variables are expressed as deviation from their respective sample averages.
} 
Table 3. Complementarity between tariff and FDI liberalization: Total Factor Productivity

\begin{tabular}{|c|c|c|c|c|c|c|c|c|}
\hline \multirow[t]{2}{*}{ Dependent variable: $\ln (\text { TFP) })_{\text {ist }}$} & \multicolumn{2}{|c|}{$I=1$} & \multicolumn{2}{|c|}{$I=2$} & \multicolumn{2}{|c|}{$I=3$} & \multicolumn{2}{|c|}{$I=4$} \\
\hline & (1) & (2) & (3) & (4) & (5) & (6) & (7) & (8) \\
\hline (Output tariff) ist $-I \times(\mathrm{FDI})$ is $_{\text {is }}$ & $\begin{array}{l}0.0003 \text { *** } \\
(0.0001)\end{array}$ & & $\begin{array}{l}0.0003 \text { *** } \\
(0.0001)\end{array}$ & & $\begin{array}{c}0.0003 \text { ** } \\
(0.0002)\end{array}$ & & $\begin{array}{l}0.0007^{* * *} \\
(0.0002)\end{array}$ & \\
\hline Country-Sector FE & Yes & Yes & Yes & Yes & Yes & Yes & Yes & Yes \\
\hline Country-Year FE & Yes & Yes & Yes & Yes & Yes & Yes & Yes & Yes \\
\hline Obs & 3,052 & 3,052 & 2,818 & 2,818 & 2,599 & 2,599 & 2,365 & 2,365 \\
\hline Adj R squared & 0.648 & 0.648 & 0.694 & 0.694 & 0.723 & 0.723 & 0.750 & 0.750 \\
\hline
\end{tabular}

Note: The dependent variable is log total factor productivity (TFP) in country i and sector s in year $t$. Independent variables are corresponding output and input tariff rates lagged $/$ years as well as their interaction with country-sector level FDI restrictiveness indicators, all of which are expressed as deviation from their respective sample averages for the sake of easier interpretation of interaction terms. Country-sector as well as country-year fixed effects are included in all columns. Standard errors in parentheses are clustered at the country-year level. Significance: $* 10$ percent; $* * 5$ percent; *** 1 percent.

Table 4. Complementarity between tariff and FDI liberalization: Labor Productivity

\begin{tabular}{|c|c|c|c|c|c|c|c|c|}
\hline \multirow[t]{2}{*}{ Dependent variable: $\ln (\mathrm{LP})$ ist } & \multicolumn{2}{|c|}{$I=1$} & \multicolumn{2}{|c|}{$I=2$} & \multicolumn{2}{|c|}{$I=3$} & \multicolumn{2}{|c|}{$I=4$} \\
\hline & (1) & (2) & (3) & (4) & (5) & (6) & (7) & (8) \\
\hline \multirow[t]{2}{*}{ (Output tariff) ist-I } & $-0.008 * *$ & $-0.005 * * *$ & $-0.009 *$ & $-0.006 * * *$ & -0.010 & $-0.005^{* *}$ & $-0.022 * * *$ & $-0.010 * * *$ \\
\hline & $(0.004)$ & $(0.002)$ & $(0.005)$ & $(0.002)$ & $(0.007)$ & $(0.002)$ & $(0.007)$ & $(0.003)$ \\
\hline \multirow[t]{2}{*}{ (Input tariff) ist-I } & $-0.019 *$ & -0.011 & $-0.017^{* *}$ & -0.007 & $-0.014^{* *}$ & -0.006 & $-0.009 * *$ & 0.001 \\
\hline & $(0.011)$ & $(0.009)$ & $(0.008)$ & $(0.005)$ & $(0.007)$ & $(0.006)$ & $(0.004)$ & $(0.003)$ \\
\hline \multirow[t]{2}{*}{ (Output tariff) $)_{\text {ist }-I \times(F D I)}$ is } & $0.0003 * *$ & & $0.0003 * *$ & & $0.0003 *$ & & $0.0007 * * *$ & \\
\hline & $(0.0001)$ & & $(0.0001)$ & & $(0.0002)$ & & $(0.0002)$ & \\
\hline (Input tariff) ist $-\mid \times(F D I)$ is & & $\begin{array}{l}0.005^{* * *} \\
(0.002)\end{array}$ & & $\begin{array}{l}0.006^{* * *} \\
(0.002)\end{array}$ & & $\begin{array}{l}0.006^{* *} \\
(0.002)\end{array}$ & & $\begin{array}{l}0.010^{* * *} \\
(0.003)\end{array}$ \\
\hline Country-Sector FE & Yes & Yes & Yes & Yes & Yes & Yes & Yes & Yes \\
\hline Country-Year FE & Yes & Yes & Yes & Yes & Yes & Yes & Yes & Yes \\
\hline Obs & 3,112 & 3,112 & 2,878 & 2,878 & 2,659 & 2,659 & 2,425 & 2,425 \\
\hline Adj R squared & 0.985 & 0.985 & 0.986 & 0.986 & 0.986 & 0.986 & 0.987 & 0.987 \\
\hline
\end{tabular}

Note: The dependent variable is log labor productivity (LP) in country i and sector s in year t. Independent variables are corresponding output and input tariff rates lagged $I$ years as well as their interaction with country-sector level FDI restrictiveness indicators, all of which are expressed as deviation from their respective sample averages for the sake of easier interpretation of interaction terms. Country-sector as well as country-year fixed effects are included in all columns. Standard errors in parentheses are clustered at the country-year level. Significance: ${ }^{*} 10$ percent; ${ }^{* *} 5$ percent; ${ }^{* * *} 1$ percent.

\section{Robustness Checks}

In this section we report evidence from a battery of robustness tests to show that the set of regressions presented in Tables 1-4 offers solid evidence of a statistically significant impact of input tariff liberalization on sector-level productivity, which is much stronger and more robust than the effect of output tariff liberalization. Moreover, the estimated coefficients on the input tariff variable are very stable across our robustness checks, and close to our baseline results. 


\section{Alternative measures of output and input tariffs}

We first check the robustness of our results to alternative measures of output and input tariffs in Table 5. For the output tariff measure, we use the effective rate of protection, which measures the net protective effect on producers of any product accounting for the structure of protection on both its inputs and outputs. Specifically, the effective rate of protection is computed as:

$$
E R P_{i s t}=\frac{\tau_{i s t}^{\text {output }}-\tau_{i s t}^{\text {input }}}{1-\sum_{k} d_{i s k}}
$$

where $d_{i s k}$ is the share of intermediate inputs $k$ in total output $s$. Unlike our previous measure, this captures the adverse effect of lower tariffs on intermediate inputs that is likely to weaken the disciplining effect of lower output tariffs for producers.

As an alternative measure of input tariffs, we calculate the indirect tariff from immediate linkages only. Specifically, we disregard indirect linkages through domestic inputs (i.e., $B=0$ in equation (1) above), which reduces to:

$$
\tau_{i s t}^{\text {input }}=\sum_{k} \alpha_{i s k} \tau_{i k t}^{\text {output }},
$$

corresponding to input tariffs employed in previous studies (e.g., Amiti and Konings, 2007; Topalova and Khandelwal, 2011).

Table 5 shows that our previous results - focusing here on explanatory variables lagged three periods - are robust across different tariff measures. ${ }^{8}$ Using the effective rate of protection instead of the output tariff rate still yields statistically insignificant results (columns 1 and 2), while the significance and magnitude of the effect of input tariffs is very close to the baseline results, regardless of whether we control for the effective rate of protection (columns 3-6).

\footnotetext{
${ }^{8}$ Robusteness checks with different lags throughout this section yield virtually identical results.
} 
Table 5. Robustness checks for baseline regressions: alternative output and input tariff measures

\begin{tabular}{|c|c|c|c|c|c|c|}
\hline \multirow[b]{2}{*}{ Dependent variable: } & \multicolumn{2}{|c|}{ Alt. output tariff } & \multicolumn{2}{|c|}{ Alt. input tariff } & \multicolumn{2}{|c|}{ Alt. output and input tariff } \\
\hline & $\ln (T F P)$ ist & $\ln (\mathrm{LP})$ ist & $\ln (T F P)_{\text {ist }}$ & In (LP)ist & $\ln (T F P)_{\text {ist }}$ & $\ln (\mathrm{LP})$ ist \\
\hline & (1) & (2) & (3) & (4) & (5) & (6) \\
\hline \multirow[t]{2}{*}{ (Output tariff) ist -3} & -0.001 & -0.001 & 0.000 & 0.000 & 0.000 & -0.001 \\
\hline & $(0.001)$ & $(0.001)$ & $(0.001)$ & $(0.001)$ & $(0.001)$ & $(0.001)$ \\
\hline \multirow[t]{2}{*}{ (Input tariff) ist-3 } & $-0.020 * *$ & $-0.022 * *$ & $-0.027 * *$ & $-0.028 *$ & $-0.028 * *$ & $-0.030 *$ \\
\hline & (0.008) & (0.009) & $(0.013)$ & $(0.014)$ & $(0.014)$ & $(0.016)$ \\
\hline Country-Sector FE & Yes & Yes & Yes & Yes & Yes & Yes \\
\hline Country-Year FE & Yes & Yes & Yes & Yes & Yes & Yes \\
\hline Obs & 3,167 & 3,237 & 3,167 & 3,237 & 3,167 & 3,237 \\
\hline Adj R squared & 0.719 & 0.970 & 0.719 & 0.970 & 0.719 & 0.970 \\
\hline
\end{tabular}

Note: The dependent variable is log total factor productivity (TFP) in columns $1,3,5$ and log labor productivity (LP) in columns $2,4,6$, both in country i and sector $\mathrm{s}$ in year $\mathrm{t}$. Independent variables are corresponding 3-years lagged output and input tariff rates. Specifically, the output tariff rate variable in columns 1-2 and 5-6 is the effective rate of protection as defined in the text, and the input tariff rate variable in columns $3-6$ is a simpler version of the baseline measure, which considers only immediate linkages in the 10 matrix. Country-sector as well as country-year fixed effects are included in all columns. Standard errors in parentheses are clustered at the country-year level. Significance: ${ }^{*} 10$ percent; ${ }^{* *} 5$ percent; ${ }^{* * *} 1$ percent.

\section{Interpolating data for missing tariff observations}

As discussed earlier, the baseline sample is discontinuous for some countries during the sample period due to missing tariff data. It is conceptually possible, albeit unlikely, that tariff data are missing in such a systematic way that biases estimation results - for instance, tariff data might be missing when they are not much changed from the previous year. As reported in columns 1 and 2 of Table 6, accounting for missing years in the tariffs data by interpolating in between available years does not alter our main results.

Table 6. Robustness checks for baseline regressions: interpolated tariff data and changes in sample

\begin{tabular}{|c|c|c|c|c|c|c|c|c|}
\hline \multirow[b]{2}{*}{ Dependent variable: } & \multicolumn{2}{|c|}{ interpolated tariff data } & \multicolumn{2}{|c|}{ excluding service sectors } & \multicolumn{2}{|c|}{ sample period up to 2007} & \multicolumn{2}{|c|}{ excluding new EU members } \\
\hline & In (TFP)ist & $\ln (\mathrm{LP})_{\text {ist }}$ & $\ln ($ TFP) ist & $\ln (\mathrm{LP})_{\text {ist }}$ & $\ln ($ TFP) ist & $\ln (\mathrm{LP})_{\text {ist }}$ & $\ln ($ TFP) ist & $\ln (\mathrm{LP})_{\text {ist }}$ \\
\hline & (1) & (2) & (3) & (4) & (5) & (6) & (7) & (8) \\
\hline (Output tariff)ist-3 & $\begin{array}{r}0.000 \\
(0.001)\end{array}$ & $\begin{array}{r}0.000 \\
(0.001)\end{array}$ & $\begin{array}{r}0.000 \\
(0.001)\end{array}$ & $\begin{array}{r}0.000 \\
(0.001)\end{array}$ & $\begin{array}{c}-0.001 \\
(0.001)\end{array}$ & $\begin{array}{c}-0.001 \\
(0.001)\end{array}$ & $\begin{array}{c}-0.001 \\
(0.002)\end{array}$ & $\begin{array}{c}-0.001 \\
(0.002)\end{array}$ \\
\hline (Input tariff) ist-3 & $\begin{array}{l}-0.017 \text { *** } \\
(0.004)\end{array}$ & $\begin{array}{l}-0.018^{* * *} \\
(0.005)\end{array}$ & $\begin{array}{l}-0.017 \text { *** } \\
(0.006)\end{array}$ & $\begin{array}{l}-0.019 * * * \\
(0.007)\end{array}$ & $\begin{array}{l}-0.016 * * \\
(0.006)\end{array}$ & $\begin{array}{l}-0.018 \text { ** } \\
(0.008)\end{array}$ & $\begin{array}{l}-0.015 \text { ** } \\
(0.006)\end{array}$ & $\begin{array}{l}-0.016 * * \\
(0.007)\end{array}$ \\
\hline Country-Sector FE & Yes & Yes & Yes & Yes & Yes & Yes & Yes & Yes \\
\hline Country-Year FE & Yes & Yes & Yes & Yes & Yes & Yes & Yes & Yes \\
\hline Obs & 3,467 & 3,537 & 2,555 & 2,610 & 2,675 & 2,675 & 2,861 & 2,931 \\
\hline Adj R squared & 0.720 & 0.970 & 0.722 & 0.967 & 0.751 & 0.977 & 0.640 & 0.988 \\
\hline
\end{tabular}

Note: The dependent variable is log total factor productivity (TFP) in columns 1, 3, 5, 7 and log labor productivity (LP) in columns 2, 4, 6, 8, both in country i and sector $s$ in year t. Independent variables are corresponding 3-years lagged output and input tariff rates. Columns 1-2 employ extended sample by interpolating tariff rates data. Columns 3-4 exclude service sectors, columns 5-6 excludes sample periods after 2007, and columns 7-8 excludes new EU member countries. Country-sector as well as country-year fixed effects are included in all columns. Standard errors in parentheses are clustered at the country-year level. Significance: ${ }^{*} 10$ percent; ${ }^{* *} 5$ percent; ${ }^{* * *} 1$ percent.

\section{Effects for different sectors}

The link between productivity gains and input tariff reductions may differ across sectors. In particular, the input channel might be expected to be stronger for manufacturing industries. In order to explore this possibility, we rerun the baseline regressions by dropping all services- 
related sectors from the sample. ${ }^{9}$ The results reported in columns 3 and 4 of Table 6 do not corroborate a stronger effect in manufacturing industries - the significance and magnitude of the estimated impact of input tariffs remains very close to the baseline results.

\section{Alternative time periods and country samples}

Productivity measures tend to behave pro cyclically. Indeed, available data suggest that TFP declined in most countries in the wake of the global financial crisis. While the regression specifications address this by controlling for country-year fixed effects, as a robustness test we restrict the sample to the pre-crisis period. The empirical results obtained on a 1991-2007 sample are broadly consistent with the baseline results (columns 5 and 6 in Table 6), i.e. we continue to find a negative and statistically significant relationship between input tariffs and productivity.

Our main results also remain stable and significant when sub-groups of countries are omitted in a systematic way. In particular, our results hold if we exclude Czech Republic, Hungary, and Slovenia, countries which experienced the most significant tariff cuts as they joined the European Union around the middle of the sample period (columns 7 and 8 in Table 6).

We also consider alternative clustering approaches, including clustering standard errors at the country-sector level. The findings, not reported here, but available upon request, indicate that the thrust of our results remains essentially unchanged.

\section{Robustness of complementarities between tariffs and barriers to FDI}

Lastly, we confirm the robustness of the results regarding complementarities between tariffs and barriers to FDI along the exactly same dimensions as above - alternative measures of input and output tariffs, interpolating missing tariff data, and excluding service sectors/post-2007 period/new EU member countries, all for both TFP and LP-in Tables 7-10.

\footnotetext{
${ }^{9}$ Specifically, we dropped water supply; sewerage, waste management and remediation activities; professional, scientific and technical activities; administrative and support service activities; arts, entertainment and recreation; and other service activities.
} 
Table 7. Robustness checks for tariff-FDI complementarity regressions: TFP; alternative output and input tariff measures

\begin{tabular}{|c|c|c|c|c|c|c|}
\hline & \multicolumn{2}{|c|}{ Alt. output tariff } & \multicolumn{2}{|c|}{ Alt. input tariff } & \multicolumn{2}{|c|}{ Alt. output and input tariff } \\
\hline \multicolumn{7}{|c|}{ Dependent variable: In (TFP) ist } \\
\hline & (1) & (2) & (3) & (4) & (5) & (6) \\
\hline (Output tariff) ist -3 & -0.002 & -0.002 & $-0.010^{*}$ & $-0.008 * *$ & -0.002 & $-0.002 *$ \\
\hline & $(0.002)$ & $(0.001)$ & $(0.006)$ & $(0.003)$ & $(0.001)$ & $(0.001)$ \\
\hline (Input tariff) ist-3 & $-0.024 * * *$ & $-0.015 * * *$ & $-0.019 *$ & -0.011 & $-0.031 * * *$ & $-0.025 * * *$ \\
\hline & $(0.008)$ & $(0.005)$ & $(0.011)$ & $(0.010)$ & $(0.012)$ & $(0.009)$ \\
\hline (Output tariff) ist-3x (FDI) is & $0.0001 *$ & & $0.0003 *$ & & $0.0001 *$ & \\
\hline & $(0.0001)$ & & $(0.0002)$ & & $(0.0000)$ & \\
\hline$(\text { Input tariff })_{\text {ist- }-3 \times} \times(F D I)$ is & & $\begin{array}{l}0.0044^{* *} \\
(0.002)\end{array}$ & & $\begin{array}{l}0.009 * * * \\
(0.003)\end{array}$ & & $\begin{array}{l}0.006^{* * *} \\
(0.002)\end{array}$ \\
\hline Country-Sector FE & Yes & Yes & Yes & Yes & Yes & Yes \\
\hline Country-Year FE & Yes & Yes & Yes & Yes & Yes & Yes \\
\hline Obs & 2,599 & 2,599 & 2,599 & 2,599 & 2,599 & 2,599 \\
\hline Adj R squared & 0.723 & 0.723 & 0.723 & 0.724 & 0.723 & 0.723 \\
\hline
\end{tabular}

Note: The dependent variable is log total factor productivity (TFP) in country i and sector s in year t. Independent variables are corresponding 3-years lagged output and input tariff rates as well as their interaction with country-sector level FDI restrictiveness indicators, all of which are expressed as deviation from their respective sample averages for the sake of easier interpretation of interaction terms. Specifically, the output tariff rate variable in columns 1-2 and 5-6 is the effective rate of protection as defined in the text, and the input tariff rate variable in columns 3-6 is a simpler version of the baseline measure, which considers only immediate linkages in the 10 matrix. Country-sector as well as country-year fixed effects are included in all columns. Standard errors in parentheses are clustered at the country-year level. Significance: $* 10$ percent; ${ }^{* *} 5$ percent; ${ }^{* * *} 1$ percent.

Table 8. Robustness checks for tariff-FDI complementarity regressions: LP; alternative output and input tariff measures

\begin{tabular}{|c|c|c|c|c|c|c|}
\hline & \multicolumn{2}{|c|}{ Alt. output tariff } & \multicolumn{2}{|c|}{ Alt. input tariff } & \multicolumn{2}{|c|}{ Alt. output and input tariff } \\
\hline \multicolumn{7}{|l|}{ Dependent variable: $\ln (\mathrm{LP})_{\text {ist }}$} \\
\hline & (1) & (2) & (3) & (4) & (5) & (6) \\
\hline (Output tariff) ist-3 & $\begin{array}{r}-0.010 \\
(0.007)\end{array}$ & $\begin{array}{l}-0.005^{* *} \\
(0.002)\end{array}$ & $\begin{array}{l}-0.010 \\
(0.007)\end{array}$ & $\begin{array}{l}-0.009 * * \\
(0.004)\end{array}$ & $\begin{array}{l}-0.002 \\
(0.002)\end{array}$ & $\begin{array}{c}-0.003 * \\
(0.001)\end{array}$ \\
\hline (Input tariff) ist-3 & $\begin{array}{l}-0.014^{* *} \\
(0.007)\end{array}$ & $\begin{array}{l}-0.006 \\
(0.006)\end{array}$ & $\begin{array}{r}-0.020 \\
(0.012)\end{array}$ & $\begin{array}{r}-0.010 \\
(0.011)\end{array}$ & $\begin{array}{l}-0.033 * * \\
(0.013)\end{array}$ & $\begin{array}{l}-0.026 * * * \\
(0.009)\end{array}$ \\
\hline (Output tariff) ist- $3 \times($ FDI) is & $\begin{array}{c}0.0003 * \\
(0.0002)\end{array}$ & & $\begin{array}{c}0.0003 \\
(0.0002)\end{array}$ & & $\begin{array}{c}0.0001 \\
(0.0001)\end{array}$ & \\
\hline (Input tariff) $\left.)_{\text {ist }-3 \times(\mathrm{FDI})}\right)_{\text {is }}$ & & $\begin{array}{l}0.006^{* *} \\
(0.002)\end{array}$ & & $\begin{array}{l}0.011 \text { *** } \\
(0.004)\end{array}$ & & $\begin{array}{l}0.007^{* * *} \\
(0.002)\end{array}$ \\
\hline Country-Sector FE & Yes & Yes & Yes & Yes & Yes & Yes \\
\hline Country-Year FE & Yes & Yes & Yes & Yes & Yes & Yes \\
\hline Obs & 2,659 & 2,659 & 2,659 & 2,659 & 2,659 & 2,659 \\
\hline Adj R squared & 0.986 & 0.986 & 0.969 & 0.969 & 0.969 & 0.969 \\
\hline
\end{tabular}

Note: The dependent variable is log labor productivity (LP) in country $i$ and sector s in yeart. Independent variables are corresponding 3-years lagged output and input tariff rates as well as their interaction with country-sector level FDI restrictiveness indicators, all of which are expressed as deviation from their respective sample averages for the sake of easier interpretation of interaction terms. Specifically, the output tariff rate variable in columns 1-2 and 5-6 is the effective rate of protection as defined in the text, and the input tariff rate variable in columns 3-6 is a simpler version of the baseline measure, which considers only immediate linkages in the IO matrix. Country-sector as well as country-year fixed effects are included in all columns. Standard errors in parentheses are clustered at the country-year level. Significance: ${ }^{*} 10$ percent; ${ }^{* *} 5$ percent; ${ }^{* * *} 1$ percent.

\section{CInternational Monetary Fund. Not for Redistribution}


Table 9. Robustness checks for tariff-FDI complementarity regressions: TFP; interpolated tariff data and changes in sample

\begin{tabular}{|c|c|c|c|c|c|c|c|c|}
\hline \multirow{2}{*}{ Dependent variable: In (TFP)ist } & \multicolumn{2}{|c|}{ interpolated tariff data } & \multicolumn{2}{|c|}{ excluding service sectors } & \multicolumn{2}{|c|}{ sample period up to 2007} & \multicolumn{2}{|c|}{ excluding new EU members } \\
\hline & & & & & & & & \\
\hline & (1) & (2) & (3) & (4) & (5) & (6) & (7) & (8) \\
\hline (Output tariff) ist-3 & $\begin{array}{l}-0.011 * * \\
(0.006)\end{array}$ & $\begin{array}{l}-0.004^{*} \\
(0.002)\end{array}$ & $\begin{array}{l}-0.022 * * * \\
(0.008)\end{array}$ & $\begin{array}{l}-0.014^{* * *} \\
(0.004)\end{array}$ & $\begin{array}{l}-0.009 \\
(0.005)\end{array}$ & $\begin{array}{l}-0.006^{* * *} \\
(0.002)\end{array}$ & $\begin{array}{l}-0.025 * * * \\
(0.008)\end{array}$ & $\begin{array}{l}-0.007^{*} \\
(0.004)\end{array}$ \\
\hline (Input tariff) ist-3 & $\begin{array}{l}-0.011 * * \\
(0.004)\end{array}$ & $\begin{array}{r}-0.007 \\
(0.005)\end{array}$ & $\begin{array}{l}-0.007 * * \\
(0.003)\end{array}$ & $\begin{array}{r}-0.004 \\
(0.004)\end{array}$ & $\begin{array}{l}-0.011 * \\
(0.006)\end{array}$ & $\begin{array}{r}0.000 \\
(0.003)\end{array}$ & $\begin{array}{l}-0.007 * * \\
(0.003)\end{array}$ & $\begin{array}{r}-0.004 \\
(0.008)\end{array}$ \\
\hline (Output tariff) ist- $3 \times$ (Direct FDI) is & $\begin{array}{l}0.0004^{* *} \\
(0.0002)\end{array}$ & & $\begin{array}{l}0.0007^{* * *} \\
(0.0002)\end{array}$ & & $\begin{array}{l}0.0003 * \\
(0.0002)\end{array}$ & & $\begin{array}{l}0.0008^{* * *} \\
(0.0002)\end{array}$ & \\
\hline (Input tariff) ist $-3 \times\left(\right.$ Direct FDI) is $_{\text {is }}$ & & $\begin{array}{l}0.004 * * \\
(0.002)\end{array}$ & & $\begin{array}{l}0.014^{* * *} \\
(0.004)\end{array}$ & & $\begin{array}{l}0.006 * * * \\
(0.002)\end{array}$ & & $\begin{array}{c}0.007^{*} \\
(0.004)\end{array}$ \\
\hline Country-Sector FE & Yes & Yes & Yes & Yes & Yes & Yes & Yes & Yes \\
\hline Country-Year FE & Yes & Yes & Yes & Yes & Yes & Yes & Yes & Yes \\
\hline Obs & 2,865 & 2,865 & 1,981 & 1,981 & 2,197 & 2,197 & 2,327 & 2,327 \\
\hline Adj R squared & 0.725 & 0.724 & 0.645 & 0.647 & 0.755 & 0.756 & 0.643 & 0.642 \\
\hline
\end{tabular}

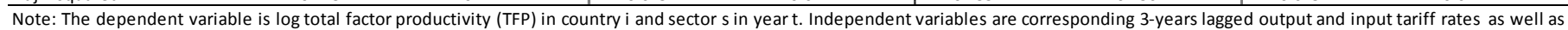

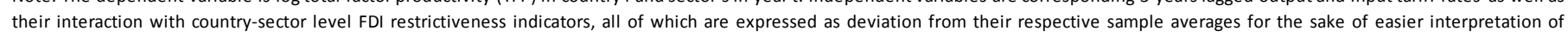
interaction terms. Columns 1-2 employ extended sample by interpolating tariff rates data. Columns 3-4 exclude service sectors, columns 5-6 excludes sample periods after 2007, and columns 7-8

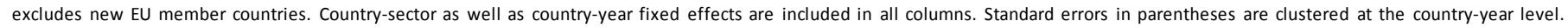
Significance: $* 10$ percent; ${ }^{* *} 5$ percent; ${ }^{* * *} 1$ percent.

Table 10. Robustness checks for tariff-FDI complementarity regressions: LP; interpolated tariff data and changes in sample

\begin{tabular}{|c|c|c|c|c|c|c|c|c|}
\hline \multirow{2}{*}{ Dependent variable: $\ln (\mathrm{LP})$ ist } & \multicolumn{2}{|c|}{ interpolated tariff data } & \multicolumn{2}{|c|}{ excluding service sectors } & \multicolumn{2}{|c|}{ sample period up to 2007} & \multicolumn{2}{|c|}{ excluding new EU members } \\
\hline & & & & & & & & \\
\hline & (1) & $(2)$ & (3) & (4) & (5) & (6) & (7) & (8) \\
\hline (Output tariff) ist-3 & $\begin{array}{l}-0.010 * \\
(0.006)\end{array}$ & $\begin{array}{l}-0.005^{* *} \\
(0.002)\end{array}$ & $\begin{array}{l}-0.023 * * \\
(0.009)\end{array}$ & $\begin{array}{l}-0.016 * * * \\
(0.005)\end{array}$ & $\begin{aligned}-0.008 \\
(0.006)\end{aligned}$ & $\begin{array}{l}-0.007^{* * *} \\
(0.003)\end{array}$ & $\begin{array}{l}-0.026 * * * \\
(0.009)\end{array}$ & $\begin{array}{l}-0.009 * \\
(0.005)\end{array}$ \\
\hline (Input tariff) ist-3 & $\begin{array}{l}-0.013 * * * \\
(0.005)\end{array}$ & $\begin{array}{r}-0.006 \\
(0.006)\end{array}$ & $\begin{array}{l}-0.008^{* *} \\
(0.003)\end{array}$ & $\begin{array}{c}0.009 * \\
(0.005)\end{array}$ & $\begin{array}{l}-0.013 * \\
(0.007)\end{array}$ & $\begin{array}{r}0.001 \\
(0.003)\end{array}$ & $\begin{array}{l}-0.007 * \\
(0.004)\end{array}$ & $\begin{array}{r}-0.002 \\
(0.009)\end{array}$ \\
\hline (Output tariff) ist- $3 \times$ (Direct FDI) is & $\begin{array}{c}0.0003 * \\
(0.0002)\end{array}$ & & 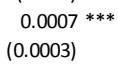 & & $\begin{array}{r}0.0003 \\
(0.0002)\end{array}$ & & $\begin{array}{l}0.0008^{* * *} \\
(0.0003)\end{array}$ & \\
\hline (Input tariff) ist- $3 \times($ Direct FDI $)$ is & & $\begin{array}{l}0.006^{* * *} \\
(0.002)\end{array}$ & & $\begin{array}{l}0.016^{* * *} \\
(0.005)\end{array}$ & & $\begin{array}{l}0.008^{* * *} \\
(0.002)\end{array}$ & & $\begin{array}{l}0.009 * * \\
(0.004)\end{array}$ \\
\hline Country-Sector FE & Yes & Yes & Yes & Yes & Yes & Yes & Yes & Yes \\
\hline Country-Year FE & Yes & Yes & Yes & Yes & Yes & Yes & Yes & Yes \\
\hline Obs & 2,925 & 2,925 & 2,031 & 2,031 & 2,197 & 2,197 & 2,387 & 2,387 \\
\hline Adj R squared & 0.969 & 0.969 & 0.984 & 0.984 & 0.990 & 0.990 & 0.987 & 0.987 \\
\hline
\end{tabular}

Note: The dependent variable is log labor productivity (LP) in country i and sector s in year t. Independent variables are corresponding 3-years lagged output and input tariff rates as well as their

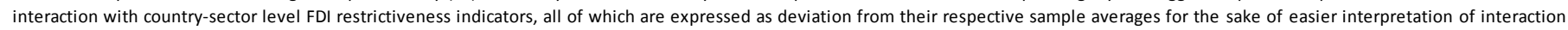
terms. Columns 1-2 employ extended sample by interpolating tariff rates data. Columns 3-4 exclude service sectors, columns 5-6 excludes sample periods after 2007, and columns 7-8 excludes new EU member countries. Country-sector as well as country-year fixed effects are included in all columns. Standard errors in parentheses are clustered at the country-year level. Significance: $* 10$ percent; $* *$ 5 percent; ${ }^{* * *} 1$ percent.

\section{Policy Implications of the Results}

Our results have three main policy implications. First, tariff reductions have been important drivers of productivity growth in the past. For the countries in our sample, input tariffs fell on average by 0.5 percentage points over the decade 1997-2007. Using a baseline semi-elasticity of 2 , this translates into an average productivity gain of about 1 percent.

Second, while tariff barriers in advanced countries have been reduced substantially over the last decades, there is still scope for further reductions, and therefore for further productivity gains, in some sectors in some countries. A back-of-the-envelope calculation of the potential productivity gains from full elimination of remaining tariffs suggests that aggregate productivity could rise by around 1 percent on average across advanced economies. These 
gains vary from a 0.2 percent gain in Japan to a 7.7 percent gain in Ireland, depending on current sector-level tariff rates as well as each sector's importance in individual country (Figure 6). ${ }^{10}$ For instance, potential gains for Ireland and Korea are estimated to be larger than those for other advanced economies. Korea, for instance, has higher remaining tariffs on average than other advanced countries in the sample - partly reflecting that its trade partners differ from those of EU countries that dominate the sample. For Ireland, a strong reliance on imported inputs especially in specific sectors - the chemical and pharmaceutical industries - is estimated to dominate the potential gains. Given their comparatively higher tariff barriers to trade, emerging and low-income economies could benefit from tariff liberalization even more than advanced economies, on average. ${ }^{11}$

Figure 6. Potential Productivity Gains from Eliminating Remaining Tariff Barriers

(In percent; red bars on right axis)

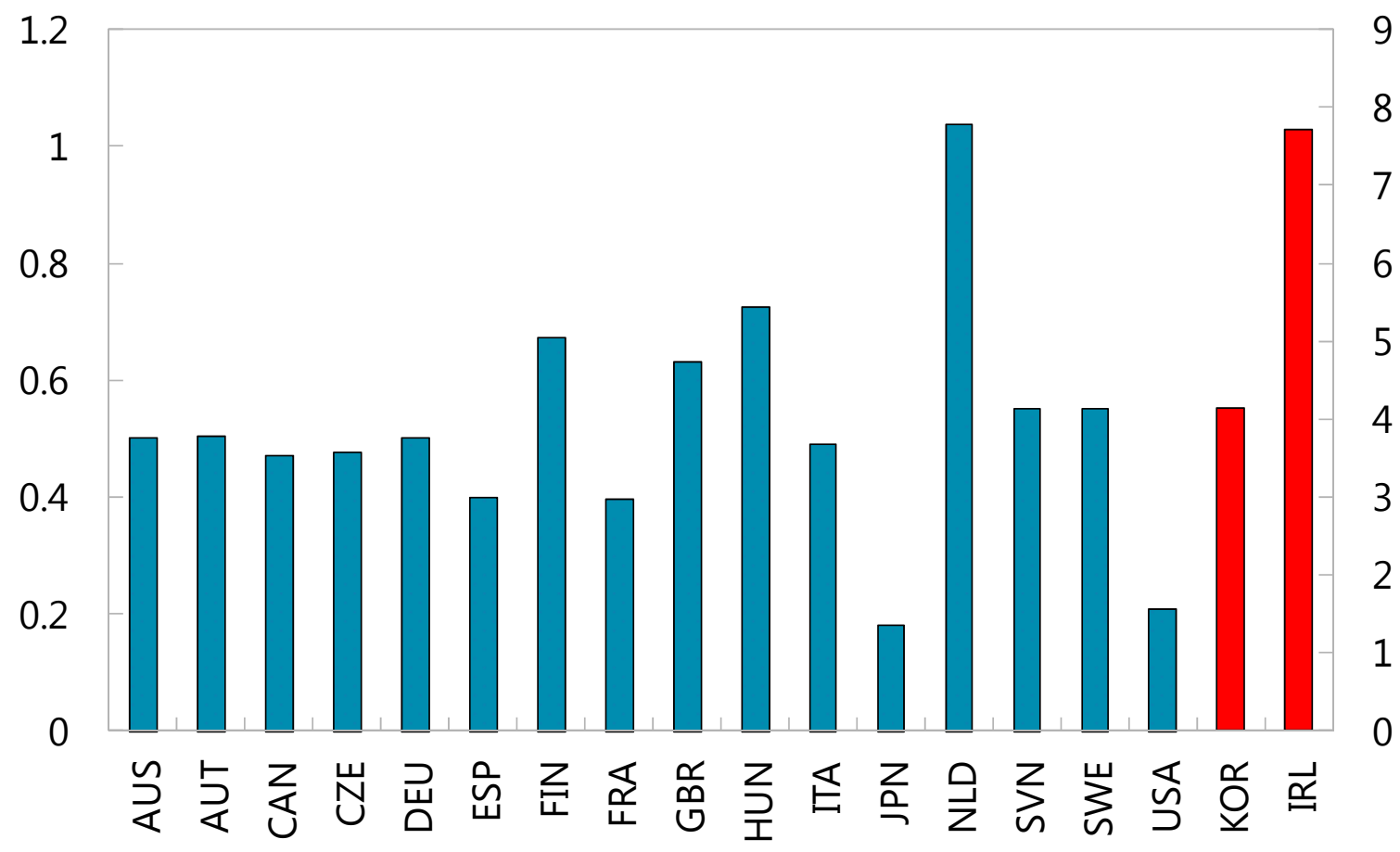

\footnotetext{
${ }^{10}$ This is based on tariff data in the latest available years - Japan and Korea are based on tariff data in 2012 and 2010, respectively, while all other countries are based on tariff data in 2013.

${ }^{11}$ Applying the same level of semi-elasticity of 2 to the latest sector-level effective input tariff rates, India, for instance, could boost TFP level by around 18 percent on average across sectors, reflecting substantially higher level of remaining tariffs than those in advanced countries.
} 
Third, the impact of further tariff reductions on productivity would be amplified if barriers to FDI were also reduced in parallel. This highlights the need for a broad liberalization agenda cutting across different areas.

\section{ConCluding Remarks}

This paper empirically reassesses the productivity gains from trade liberalization in a crosscountry cross-industry time-series framework that captures productivity effects arising within each firm as well as from reallocation of resources across firms. Our main result is that trade liberalization in upstream industries matters more for sector-level productivity than liberalization in the sector considered itself. This is consistent with, but generalizes, the findings of recent papers at the firm level.

Our findings provide a clear case for further liberalization efforts to raise productivity and output in advanced economies - all the more so as the estimates vastly under-state the potential gains as they ignore the (presumably much larger) benefits to be reaped from easing non-tariff trade barriers. Indeed, recent trade liberalization efforts have increasingly centered on reducing non-tariff barriers, particularly in services sectors, from expediting customs procedures to intellectual property provisions. Ongoing efforts to enhance data availability on non-tariff barrier measures will help complement existing studies of the impact of tariff liberalization (e.g., Bachetta and Beverelli, 2012; Staiger, 2015). Given their comparatively higher barriers to trade, productivity gains for emerging and low-income countries could conceivably be even higher.

The results also highlight the existence of complementarities between reductions in barriers to trade and reforms in other areas. While our focus has been on complementarities between reductions in trade and FDI barriers, the productivity effects of trade liberalization could also vary depending on other existing policies and institutions, such as in the areas of labor or product markets. For instance, the effect of tariff liberalization could be greater when domestic product market ("behind-the-border barriers") and labor market regulations are less stringent. Recent theoretical work by Helpman and Itskhoki (2014) shows that in the wake of trade liberalization, labor market frictions can persistently depress productivity during the transition to the new steady state as they result in misallocation of labor - consistent with the empirical results of Aghion et al. (2008) using state-level data for India. Future empirical research could investigate the existence of complementarities between trade liberalization and other types of structural reforms. 


\section{REFERENCES}

Aghion, Philippe, Nick Bloom, Richard Blundell, Rachel Griffith, and Peter Howitt. 2005. "Competition and Innovation: an Inverted-U Relationship." Quarterly Journal of Economics 120 (2): 701-28.

Aghion, Philippe, Robin Burgess, Stephen J. Redding, and Fabrizio Zilibotti. 2008. "The Unequal Effects of Liberalization: Evidence from Dismantling the License Raj in India." American Economic Review, 98(4): 1397-1412.

Amiti, Mary, and Jozef Konings. 2007. "Trade Liberalization, Intermediate Inputs, and Productivity: Evidence from Indonesia.” American Economic Review 97 (5): 1611-38.

Amiti, Mary, and Amit Khandelwal, 2013, "Import Competition and Quality Upgrading." The Review of Economics and Statistics, 95(2): 476-490.

Bacchetta, Marc, and Cosimo Beverelli. 2012. "Non-Tariff Measures and the WTO.” VOXEU.

Bourle, Renaud, Gilbert Cette, Jimmy Lopez, Jacques Mairesse, and Giuseppe Nicoletti. 2013. "Do Product Market Regulations in Upstream Sectors Curb Productivity Growth? Panel Data Evidence for OECD Countries.” The Review of Economics and Statistics, 95(5): 1750-1768.

Corden, Max. 1966. "The Structure of a Tariff System and the Effective Protective Rate." Journal of Political Economy 74 (3): 221-37.

Ethier, Wilfred. 1982. "National and International Returns to Scale in the Modern Theory of International Trade." American Economic Review, 72 (3): 389-405.

Fernandes, Ana. 2007. "Trade Policy, Trade Volumes and Plant-level Productivity in Colombian Manufacturing Industries." Journal of International Economics, 71 (1): 51-72.

Grossman, Gene and Elhanan Helpman. 1991. "Quality Ladders in the Theory of Growth." Review of Economic Studies 58 (1): 43-61.

Halpern, László, Miklós Koren, and Adam Szeidl. 2015. "Imported Inputs and Productivity." American Economic Review, 105 (12): 3660-3703.

Helpman, Elhanan and Oleg Itskhoki, 2014, "Firms, Trade and Labor Market Dynamics." unpupblished manuscript, Princeton University.

Helpman, Elhanan and Paul Krugman. 1985. Market Structure and Foreign Trade. Cambridge: MIT Press.

Kasahara, Hiroyuki, and Joel Rodrigue. 2008. "Does the Use of Imported Intermediates Increase Productivity? Plant-level Evidence." Journal of Development Economics, 87 (1): 10618. 
Markusen, James. 1989, "Trade in Producer Services and in other Specialized, Intermediate Inputs.” American Economic Review 79 (1): 85-95.

Melitz, Marc. 2003. "The Impact of Trade on Intra-Industry Reallocations and Aggregate Industry Productivity." Econometrica, 71(6): 1695-725.

Melitz, Marc, and Gianmarco Ottaviano. 2008. "Market size, trade, and productivity." The Review of Economic Studies 75(1): 295-316.

Pavcnik, Nina. 2002. "Trade Liberalization, Exit, and Productivity Improvements: Evidence from Chilean Plants." Review of Economic Studies, 69 (1): 245-76.

Staiger, Robert. 2015. "Non-Tariff Measures and the WTO.” Unpublished working paper. Dartmouth College, Hanover.

Topalova, Petia, and Amit Khandelwal. 2011. "Trade Liberalization and Firm Productivity: The Case of India." The Review of Economics and Statistics, 93 (3): 995-1009. 


\begin{tabular}{cl} 
Annex 1. & Sample of Countries \\
\hline 1 & Australia \\
2 & Austria \\
3 & Canada \\
4 & Czech Republic \\
5 & Germany \\
6 & Spain \\
7 & Finland \\
8 & France \\
9 & United Kingdom \\
10 & Hungary \\
11 & Ireland \\
12 & Italy \\
13 & Japan \\
14 & Korea \\
15 & Netherlands \\
16 & Slovenia \\
17 & Sweden \\
18 & United States \\
\hline
\end{tabular}


Annex 2. Description of Sectors

\begin{tabular}{l|c}
\hline Description & ISIC Rev 4. Code \\
\hline Agriculture, forestry, and fishing & A \\
Mining and quarrying & $10-12$ \\
Food products, beverages and tobacco & $13-15$ \\
Textiles, wearing apparel, leather and related prodcuts & $16-18 \mathrm{a}$ \\
Wood products & $16-18 \mathrm{~b}$ \\
Paper products; printing and reproduction of recorded media & 19 \\
Coke and refined petroleum products & $20-21$ \\
Chemicals and chemical products & $22-23 \mathrm{a}$ \\
Rubber and plastics products & $22-23 b$ \\
Other non-metallic mineral products & $24-25$ \\
Basic metals and fabricated metal products, except machinery and equipment & $26-27$ \\
Electrical and optical equipment & 28 \\
Machinery and equipment n.e.c. & $29-30$ \\
Transport equipment & $31-33$ \\
Other manufacturing; repair and installation of machinery and equipment & $\mathrm{D}-\mathrm{E}$ \\
Electricity, gas, and water supply & $\mathrm{M}-\mathrm{N}$ \\
Professional, scientific, technical, administrative and support service activities & $\mathrm{R}-\mathrm{S}$ \\
Arts, entertainment, recreation and other service activities & \\
\hline
\end{tabular}


Annex 3. Baseline Sample Data Countries and Sectors

\begin{tabular}{|c|c|c|c|c|c|c|c|c|c|c|c|c|c|c|c|c|}
\hline \begin{tabular}{|l} 
Country \\
ISIC Rev. 4 Sector Code \\
\end{tabular} & A & B & $10-12$ & 13-15 & $16-18$ & 19 & $20-21$ & $22-23$ & $24-25$ & $26-27$ & 28 & $29-30$ & $31-33$ & D-E & $M-N$ & R-S \\
\hline Australia & $91^{\prime}, 933^{\prime \prime-07 '}$ & $91^{\prime}, 93^{\prime \prime}-07^{\prime}$ & $91^{\prime}, 933^{\prime \prime}-07{ }^{\prime}$ & $91^{\prime}, 933^{\prime \prime}-07^{\prime}$ & $91^{\prime}, 933^{\prime \prime}-07{ }^{\prime}$ & 91', 93"-07' & 91', 93"-07' & 91', 93"-07' & 91', 93"-07' & $91^{\prime}, 93^{\prime \prime}-07^{\prime}$ & $91^{\prime}, 933^{\prime \prime}-07{ }^{\prime}$ & $91^{\prime}, 933^{\prime \prime}-07{ }^{\prime}$ & $91^{\prime}, 933^{\prime \prime}-07{ }^{\prime}$ & 91', 93"-07' & $91^{\prime}, 93^{\prime \prime}-07^{\prime}$ & 91', 93"-07' \\
\hline Austria & $95^{\prime}-09^{\prime}$ & $95^{\prime}-09^{\prime}$ & $95^{\prime}-09^{\prime}$ & $95 '-09^{\prime}$ & - & $95 '-09^{\prime}$ & $95 '-09^{\prime}$ & - & 95'-09' & $95 '-09^{\prime}$ & $95 '-09^{\prime}$ & $955^{-}-09^{\prime}$ & $955^{-}-09^{\prime}$ & $95 \cdot-09$ ' & $95 '-09^{\prime}$ & $95 '-09^{\prime}$ \\
\hline Canada & 93', 95'-10' & 93', 95'-10' & 93', 95'-10' & 93', 95'-10' & 93', 95'-10' & 93', 95'-10' & 93', 95'-10' & 93', 95'-10' & 93', 95'-10' & 93', 95'-10' & 93', 95'-10' & 93', 95'-10' & 93', 95'-10' & 93', 95'-10' & 93', 95'-10' & 93', 95'-10' \\
\hline Czech Republic & $96^{\prime}-07^{\prime}$ & $96^{\prime}-07^{\prime}$ & $96^{\prime}-07^{\prime}$ & $966^{\prime}-07^{\prime}$ & $96^{\prime}-07^{\prime}$ & $96^{\prime}-07^{\prime}$ & $96^{\prime}-07^{\prime}$ & $96^{\prime}-07^{\prime}$ & $96^{\prime}-07^{\prime}$ & $96^{\prime}-07^{\prime}$ & $96^{\prime}-07 \prime^{\prime}$ & $96^{\prime}-07^{\prime}$ & $96^{\prime}-07^{\prime}$ & $96^{\prime}-07^{\prime}$ & $96^{\prime}-07^{\prime}$ & $96^{\prime}-07^{\prime}$ \\
\hline Germany & 94'-09' & 94'-09' & 94'-09' & 94'-09' & - & $94^{\prime}-09^{\prime}$ & 94'-09' & - & $94^{\prime}-09^{\prime}$ & 94'-09' & 94'-09' & $94^{\prime}-09^{\prime}$ & 94'-09' & 94'-09' & 94'-09' & $94^{\prime}-09^{\prime}$ \\
\hline Spain & 94'-09' & 94'-09' & $94^{\prime}-09^{\prime}$ & $94^{\prime}-09^{\prime}$ & - & 94'-09' & $94^{\prime}-09^{\prime}$ & - & 94'-09' & 94'-09' & 94'-09' & 94'-09' & $94^{\prime}-09^{\prime}$ & 94'-09' & 94'-09' & $94^{\prime}-09^{\prime}$ \\
\hline Finland & $955^{\prime}-12^{\prime}$ & 95'-12' & $95^{\prime}-12^{\prime}$ & $95^{\prime}-12^{\prime}$ & - & $95^{\prime}-12^{\prime}$ & $95^{\prime}-12^{\prime}$ & - & $95^{\prime}-12^{\prime}$ & $95^{\prime}-12^{\prime}$ & 95'-12' & $95^{\prime}-12^{\prime}$ & $95^{\prime}-12^{\prime}$ & $95^{\prime}-12^{\prime}$ & $95 '-12$ ' & $955^{-}-122^{\prime}$ \\
\hline France & 94'-09' & 94'-09' & 94'-09' & 94'-09' & - & 94'-09' & 94'-09' & - & 94'-09' & 94'-09' & 94'-09' & 94'-09' & 94'-09' & 94'-09' & 94'-09' & $94^{\prime}-09^{\prime}$ \\
\hline United Kingdom & 94'-09' & 94'-09' & 94'-09' & 94'-09' & - & 94'-09' & 94'-09' & - & 94'-09' & 94'-09' & 94'-09' & 94'-09' & 94'-09' & 94'-09' & 94'-09' & $94^{\prime}-09^{\prime}$ \\
\hline Hungary & $96^{\prime}-07^{\prime}$ & $966^{\prime}-07^{\prime}$ & $966^{\prime}-07^{\prime}$ & 96'-07' & $966^{\prime}-07^{\prime}$ & $966^{\prime}-07^{\prime}$ & $966^{\prime}-07^{\prime}$ & - & $966^{\prime}-07^{\prime}$ & 96'-07' & $966^{\prime}-07^{\prime}$ & $966^{\prime}-07^{\prime}$ & $966^{\prime}-07^{\prime}$ & $966^{\prime}-07^{\prime}$ & 96'-07' & $966^{\prime}-07^{\prime}$ \\
\hline Ireland & 94'-07' & 94'-07' & $94^{\prime}-07^{\prime}$ & $94^{\prime}-07^{\prime}$ & $94^{\prime}-07^{\prime}$ & - & 94'-07' & $94^{\prime}-07^{\prime}$ & $94^{\prime}-07^{\prime}$ & 94'-07' & $94^{\prime}-07^{\prime}$ & $94^{\prime}-07^{\prime}$ & $94^{\prime}-07^{\prime}$ & $94^{\prime}-07^{\prime}$ & 94'-07' & 94'-07' \\
\hline Italy & 94'-09' & 94'-09' & 94'-09' & 94'-09' & - & 94'-09' & 94'-09' & - & 94'-09' & 94'-09' & 94'-09' & 94'-09' & 94'-09' & 94'-09' & 94'-09' & $94^{\prime}-09^{\prime}$ \\
\hline Japan & $95^{\prime}-09^{\prime}$ & $95^{\prime}-09^{\prime}$ & $95^{\prime}-09^{\prime}$ & $95^{\prime}-09^{\prime}$ & - & $95^{\prime}-09^{\prime}$ & $95^{\prime}-09^{\prime}$ & - & $95^{\prime}-09^{\prime}$ & $95^{\prime}-09^{\prime}$ & $95^{\prime}-09^{\prime}$ & $95^{\prime}-09^{\prime}$ & $95 '-09^{\prime}$ & $95^{\prime}-09^{\prime}$ & $95^{\prime}-09^{\prime}$ & $95^{\prime}-09^{\prime}$ \\
\hline Korea & $\begin{array}{l}96^{\prime}, 99^{\prime}, 02^{\prime}, 04^{\prime}, \\
06^{\prime}-10^{\prime}\end{array}$ & $\begin{array}{c}96^{\prime}, 99^{\prime}, 02^{\prime}, 04^{\prime}, \\
06^{\prime}-10^{\prime}\end{array}$ & $\begin{array}{c}96^{\prime}, 99^{\prime}, 02^{\prime}, 04^{\prime}, \\
06^{\prime}-10^{\prime}\end{array}$ & $\begin{array}{c}96^{\prime}, 99^{\prime}, 02^{\prime}, 04^{\prime}, \\
06^{\prime}-10^{\prime}\end{array}$ & $\begin{array}{c}96^{\prime}, 99^{\prime}, 02^{\prime}, 04^{\prime}, \\
06^{\prime}-10^{\prime}\end{array}$ & $\begin{array}{c}96^{\prime}, 99^{\prime}, 02^{\prime}, 04^{\prime}, \\
06^{\prime}-10^{\prime}\end{array}$ & $\begin{array}{c}96^{\prime}, 99^{\prime}, 02^{\prime}, 04^{\prime}, \\
06^{\prime}-10^{\prime}\end{array}$ & $\begin{array}{c}96^{\prime}, 99^{\prime}, 02^{\prime}, 04^{\prime}, \\
06^{\prime}-10^{\prime}\end{array}$ & $\begin{array}{c}96^{\prime}, 99^{\prime}, 02^{\prime}, 04^{\prime}, \\
06^{\prime}-10^{\prime}\end{array}$ & $\begin{array}{c}96^{\prime}, 99^{\prime}, 02^{\prime}, 04^{\prime}, \\
06^{\prime}-10^{\prime}\end{array}$ & $\begin{array}{c}96^{\prime}, 99^{\prime}, 02^{\prime}, 04^{\prime}, \\
06^{\prime}-10^{\prime}\end{array}$ & $\begin{array}{c}96^{\prime}, 99^{\prime}, 02^{\prime}, 04^{\prime}, \\
06^{\prime}-10^{\prime}\end{array}$ & $\begin{array}{c}96^{\prime}, 99^{\prime}, 02^{\prime}, 04^{\prime}, \\
06^{\prime}-10^{\prime}\end{array}$ & $\begin{array}{c}96^{\prime}, 99^{\prime}, 02^{\prime}, 04^{\prime}, \\
06^{\prime}-10^{\prime}\end{array}$ & - & $\begin{array}{l}\text { 96', 99',02', 04', } \\
06^{\prime}-10^{\prime}\end{array}$ \\
\hline Netherlands & $94^{\prime}-12^{\prime}$ & $94^{\prime}-12^{\prime}$ & $94^{\prime}-12^{\prime}$ & $94^{\prime}-12^{\prime}$ & - & $94^{\prime}-12^{\prime}$ & $94^{\prime}-12^{\prime}$ & - & $94^{\prime}-12^{\prime}$ & $94^{\prime}-12^{\prime}$ & $94^{\prime}-12^{\prime}$ & $94^{\prime}-12^{\prime}$ & $94^{\prime}-12^{\prime}$ & $94^{\prime}-12^{\prime}$ & $94^{\prime}-12^{\prime}$ & $94^{\prime}-12^{\prime}$ \\
\hline Slovenia & $99^{\prime}, 01^{\prime}-06^{\prime}$ & 99', 01'-06' & 99', 01'-06' & $99^{\prime}, 01^{\prime}-06^{\prime}$ & 99', 01'-06' & 99', 01'-06' & $99^{\prime}, 01^{\prime}-06^{\prime}$ & 99', 01'-06' & $99^{\prime}, 01^{\prime}-06^{\prime}$ & 99', 01'-06' & 99', 01'-06' & 99', 01'-06' & 99', 01'-06' & 99', 01'-06' & 99', 01'-06' & 99', 01'-06' \\
\hline Sweden & $95 '-11$ ' & $95^{\prime}-11^{\prime}$ & $95^{\prime}-11^{\prime}$ & 95'-11' & - & $95^{\prime}-11^{\prime}$ & $95^{\prime}-11^{\prime}$ & 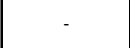 & $95^{\prime}-111^{\prime}$ & $95^{\prime}-111^{\prime}$ & $95^{\prime}-11^{\prime}$ & 95'-11' & $95^{\prime}-11^{\prime}$ & $95^{\prime}-11^{\prime}$ & $95^{\prime}-11^{\prime}$ & $95^{\prime}-111^{\prime}$ \\
\hline United States & 91'-09' & 91'-09' & 91'-09' & 91'-09' & 91'-09' & 91'-09' & 91'-09' & 91'-09' & 91'-09' & 91'-09' & 91'-09' & 91'-09' & 91'-09' & 91'-09' & 91'-09' & 91'-09' \\
\hline
\end{tabular}

CInternational Monetary Fund. Not for Redistribution 
Annex 4. Concordance between FDI restrictiveness indicators and the baseline data

FDI Regulatory Restrictiveness Index

Agriculture, Fisheries, and Forestry

Mining \& Quarrying (incl. Oil extr.)

Food and other

Oil ref. \& Chemicals

Metals, machinery and other minerals

Electric, electronics, and other

Transport equipment

Electricity

Construction

Business services
ISIC Rev 4. Code

A

B

10-12; 13-15; 16-18

19; 20-21; 22-23a

22-23b; 24-25; 28

26-27

29-30

D-E

$\mathrm{F}$

$\mathrm{M}-\mathrm{N}$ 